Check for updates

Cite this: J. Mater. Chem. A, 2020, 8 19502

Received 6th July 2020

Accepted 9th September 2020

DOI: $10.1039 / \mathrm{d} 0 \operatorname{ta0} 6608 \mathrm{~g}$

rsc.li/materials-a

\section{Lithiation of $\mathrm{V}_{2} \mathrm{O}_{3}\left(\mathrm{SO}_{4}\right)_{2}-\mathrm{a}$ flexible insertion host $\uparrow$}

\author{
Stephanie F. Linnell, (D) a Julia L. Payne, (D) a David M. Pickup, ${ }^{\text {b }}$ Alan V. Chadwick, ${ }^{\text {b }}$ \\ A. Robert Armstong (D) a and John T. S. Irvine (D) *a
}

\begin{abstract}
Materials that display strong capabilities for lithium insertion without significant change in unit cell size on cycling are of considerable importance for electrochemical applications. Here, we present $\mathrm{V}_{2} \mathrm{O}_{3}\left(\mathrm{SO}_{4}\right)_{2}$ as a host for lithium-ion batteries. Electrochemically, $2.0 \mathrm{Li}^{+}$ions can be inserted, giving $\mathrm{Li}_{2} \mathrm{~V}_{2} \mathrm{O}_{3}\left(\mathrm{SO}_{4}\right)_{2}$ with an oxidation state of $\mathrm{V}^{4+}$, as determined by $\mathrm{X}$-ray absorption spectroscopy. The capacity of $\mathrm{V}_{2} \mathrm{O}_{3}\left(\mathrm{SO}_{4}\right)_{2}$ can be increased from $157 \mathrm{~mA} \mathrm{~h} \mathrm{~g}^{-1}$ to $313 \mathrm{~mA} \mathrm{~h} \mathrm{~g}^{-1}$ with the insertion of two additional $\mathrm{Li}^{+}$ions which would drastically improve the energy density of this material, but this would be over a wider potential range. Chemical lithiation using $n$-butyllithium was performed and characterisation using a range of techniques showed that a composition of $\mathrm{Li}_{4} \mathrm{~V}_{2} \mathrm{O}_{3}\left(\mathrm{SO}_{4}\right)_{2}$ can be obtained with an oxidation state of $\mathrm{V}^{3+}$. Structural studies of the lithiated materials by $\mathrm{X}$-ray diffraction showed that up to $4.0 \mathrm{Li}^{+}$ions can be inserted into $\mathrm{V}_{2} \mathrm{O}_{3}\left(\mathrm{SO}_{4}\right)_{2}$ whilst maintaining its framework structure.
\end{abstract}

\section{Introduction}

Materials that can reversibly incorporate large numbers of ions balanced by redox changes in the host lattice are a subject of much interest, with important applications such as electrochromics and battery electrodes. One such application is in the search for less expensive positive electrode materials for high energy density lithium-ion batteries (LIBs). Consequently, great efforts have been devoted to the search for crystal structures that allow a large amount of lithium storage at high redox potentials but remain structurally stable on cycling. ${ }^{1}$ Polyanion compounds (phosphates, sulfates) are promising candidates due to their structural stability and higher operating potentials compared to oxides. ${ }^{2,3}$ Among them $\mathrm{LiFePO}_{4}$ has been extensively studied and commercialised, but its energy density $\left(\sim 580 \mathrm{~W} \mathrm{~h} \mathrm{~kg}^{-1}\right)$ is limited due to its relatively low operating voltage of $3.45 \mathrm{~V}$ vs. $\mathrm{Li}^{+} / \mathrm{Li}^{0}{ }^{0,5}$ Tavorite-structured compounds including $\mathrm{LiFeSO}_{4} \mathrm{~F},{ }^{6,7} \mathrm{LiVPO}_{4} \mathrm{~F},{ }^{8-12}$ and $\mathrm{LiVPO}_{4} \mathrm{O},{ }^{13-15}$ operate at higher voltages, are structurally stable and are considered attractive alternatives. In particular, the vanadium based materials have attracted considerable interest, due to the ability to adopt a range of oxidation states, $2+, 3+, 4+$ and $5+$, enabling them to insert/extract reversibly-more than one $\mathrm{Li}^{+}$ion per transition metal ion. The $\mathrm{Li}^{+}$extraction/insertion in $\mathrm{LiVPO}_{4} \mathrm{~F}$ is associated with two redox processes and when the two reactions are utilised this material can achieve a specific capacity of

${ }^{a}$ School of Chemistry, University of St Andrews, St Andrews, Fife, KY16 9ST, UK. E-mail: jtsi@st-andrews.ac.uk

${ }^{b}$ School of Physical Science, University of Kent, Canterbury, CT2 7NH, UK

$\dagger$ Electronic supplementary information (ESI) available: More Rietveld refinements and Rietveld refinement results, additional electrochemical data, and EXAFS analysis. See DOI: 10.1039/d0ta06608g
$312 \mathrm{~mA} \mathrm{~h} \mathrm{~g}^{-1}$. The insertion of $\mathrm{Li}^{+}$occurs at $1.80 \mathrm{~V} v s . \mathrm{Li}^{+} / \mathrm{Li}^{0}$ and is associated with the $\mathrm{V}^{3+} / \mathrm{V}^{2+}$ redox couple and extraction of $\mathrm{Li}^{+}$ occurs via two plateaux at $4.24 \mathrm{~V}$ and $4.28 \mathrm{Vvs.} \mathrm{Li}^{+} / \mathrm{Li}^{0}$ associated with the $\mathrm{V}^{4+} / \mathrm{V}^{3+}$ redox couple. ${ }^{12}$ Structural studies have revealed shifts from the triclinic $\mathrm{LiVPO}_{4} \mathrm{~F}$ pristine phase to monoclinic $\mathrm{Li}_{2} \mathrm{VPO}_{4} \mathrm{~F}$ and $\mathrm{VPO}_{4} \mathrm{~F}$ phases along with unit cell volume expansions/contractions but with retention of the $\mathrm{VPO}_{4} \mathrm{~F}$ framework on cycling. ${ }^{12}$ As for $\mathrm{LiVPO}_{4} \mathrm{O}$, this material can also exploit two redox couples and thereby deliver a specific capacity of $318 \mathrm{~mA} \mathrm{~h} \mathrm{~g}^{-1} \cdot{ }^{12}$ The insertion of $\mathrm{Li}^{+}$is associated with the $\mathrm{V}^{3+}$ / $\mathrm{V}^{4+}$ redox couple, with three short plateaux at $2.45 \mathrm{~V}, 2.21 \mathrm{~V}$ and $2.04 \mathrm{~V}$ attributed to the formation of $\mathrm{Li}_{1.5} \mathrm{VPO}_{4} \mathrm{O}, \mathrm{Li}_{1.75} \mathrm{VPO}_{4} \mathrm{O}$ and $\mathrm{Li}_{2} \mathrm{VPO}_{4} \mathrm{O}$, respectively. Over the higher voltage range, $\mathrm{Li}^{+}$is extracted with one plateau observed at $3.95 \mathrm{~V}$ associated with the $\mathrm{V}^{4+} / \mathrm{V}^{5+}$ redox couple and the formation of $\varepsilon-\mathrm{VPO}_{4} \mathrm{O} .{ }^{13}$ The $\mathrm{Li}_{x} \mathrm{VPO}_{4} \mathrm{O}(0<x<2)$ phases can be indexed to different space groups, showing unit cell volume expansions/contractions and the $\mathrm{VPO}_{4} \mathrm{O}$ framework is maintained on cycling $v s . \mathrm{Li}^{+} / \mathrm{Li}^{0}$ with changes in the $\mathrm{V}-\mathrm{O}$ bond distances for the different phases, due to the formation of the $\mathrm{V}=\mathrm{O}$ bond within the $\mathrm{VO}_{6}$ octahedra for the $\mathrm{V}^{4+}$ and $\mathrm{V}^{5+}$ phases, which is absent for the $\mathrm{V}^{3+}$ phase. ${ }^{13}$

Other materials of interest include the vanadyl phosphate, $\mathrm{Li}_{4} \mathrm{VO}\left(\mathrm{PO}_{4}\right)_{2}$. This material operates at a relatively high voltage of $4.1 \mathrm{~V} v s . \mathrm{Li}^{+} / \mathrm{Li}^{0}$ and exhibits a reversible capacity of $70 \mathrm{~mA} \mathrm{~h} \mathrm{~g}{ }^{-1}$ which is associated with the $\mathrm{V}^{4+} / \mathrm{V}^{5+}$ redox couple. ${ }^{16,17}$ The $\mathrm{PO}_{4}{ }^{3-}$ polyanion in $\mathrm{Li}_{4} \mathrm{VO}\left(\mathrm{PO}_{4}\right)_{2}$ has been replaced with the more electronegative $\mathrm{SO}_{4}{ }^{2-}$ polyanion to give $\mathrm{Li}_{2} \mathrm{VO}\left(\mathrm{SO}_{4}\right)_{2} \cdot{ }^{18} \mathrm{Li}_{2} \mathrm{VO}\left(\mathrm{SO}_{4}\right)_{2}$ shows a plateau at $4.7 \mathrm{~V}$ vs. $\mathrm{Li}^{+} / \mathrm{Li}^{0}$ associated with the $\mathrm{V}^{5+} / \mathrm{V}^{4+}$ redox couple and delivers a revers-

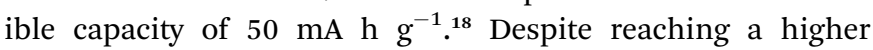
potential, vanadium-based materials that utilise the $\mathrm{SO}_{4}{ }^{2-}$ polyanion remain underexplored. ${ }^{18-21}$ Vanadium sulfates are attractive candidate compounds and while the search for new 
crystal structures and compositions is ongoing, there are existing vanadium sulfates that can be explored. ${ }^{18,22}$

$\mathrm{V}_{2} \mathrm{O}_{3}\left(\mathrm{SO}_{4}\right)_{2}$ can accept four $\mathrm{Li}^{+}$ions, delivering a theoretical capacity of $313 \mathrm{~mA} \mathrm{~h} \mathrm{~g}^{-1}$. Here, we study the $\mathrm{Li}^{+}$insertion into $\mathrm{V}_{2} \mathrm{O}_{3}\left(\mathrm{SO}_{4}\right)_{2}$ using two methods (1) electrochemical lithiation and (2) chemical lithiation using $n$-butyllithium. $\mathrm{V}_{2} \mathrm{O}_{3}\left(\mathrm{SO}_{4}\right)_{2}$ positive electrodes were cycled in Swagelok-type cells between $4.20 \mathrm{~V}$ and $1.95 \mathrm{~V} v s . \mathrm{Li}^{+} / \mathrm{Li}^{0}$ and examined $e x$ situ by means of X-ray absorption spectroscopy, infrared spectroscopy and powder Xray diffraction studies to reveal the phase evolution and structural changes which occur at different stages during the lithiation and delithiation process. $\mathrm{V}_{2} \mathrm{O}_{3}\left(\mathrm{SO}_{4}\right)_{2}$ was also chemically lithiated to insert two additional $\mathrm{Li}^{+}$ions. X-ray diffraction studies, inductively coupled plasma optical emission spectroscopy analysis and $\mathrm{X}$-ray absorption spectroscopy measurements were carried out to understand the structural evolution accompanying the chemical insertion of $\mathrm{Li}^{+}$ions.

\section{Experimental}

\section{Synthesis of $\mathrm{V}_{2} \mathrm{O}_{3}\left(\mathrm{SO}_{4}\right)_{2}$}

$\mathrm{V}_{2} \mathrm{O}_{3}\left(\mathrm{SO}_{4}\right)_{2}$ was synthesised by modifying a method reported by Richter et al. ${ }^{23} \mathrm{~V}_{2} \mathrm{O}_{5}$ (Sigma Aldrich, $\geq 99.6 \%, 3.64 \mathrm{~g}$ ) was stirred with an excess of concentrated sulfuric acid (Fischer, $>95 \%, 30$ $\mathrm{mL}$ ) at $140{ }^{\circ} \mathrm{C}$ for $48 \mathrm{~h}$ according to eqn (1).

$$
\mathrm{V}_{2} \mathrm{O}_{5}+2 \mathrm{H}_{2} \mathrm{SO}_{4} \rightarrow \mathrm{V}_{2} \mathrm{O}_{3}\left(\mathrm{SO}_{4}\right)_{2}+2 \mathrm{H}_{2} \mathrm{O}
$$

Once cooled, the product was filtered under vacuum and washed with cold concentrated $\mathrm{H}_{2} \mathrm{SO}_{4}$, followed by a further washing with $\mathrm{CF}_{3} \mathrm{COOH}$ (Alfa Aesar, 99\%) and finally dried at $200{ }^{\circ} \mathrm{C}$ overnight. The product was stored and handled in an argon filled glovebox due to its hygroscopicity.

\section{Electrochemical lithiation}

Electrodes were prepared by ball-milling $80 \mathrm{wt} \%$ active material with $20 \mathrm{wt} \%$ carbon super C65 (Imerys) at $300 \mathrm{rpm}$ under argon for $30 \mathrm{~min}$. A Fritsch Pulverisette planetary ball mill was used with $10 \mathrm{~mm}$ diameter zirconia milling balls. Electrochemical tests of the $\mathrm{V}_{2} \mathrm{O}_{3}\left(\mathrm{SO}_{4}\right)_{2}$ positive electrodes were performed in Swagelok type cells which were assembled in an argon filled glovebox. Positive electrodes were separated from the Li metal disc negative electrode by a Whatman GF/D borosilicate glass fibre sheet saturated with $1 \mathrm{M} \mathrm{LiPF}_{6}$ in ethylene carbonate/ dimethyl carbonate $[1: 1(\mathrm{w} / \mathrm{w})](\mathrm{LP} 30, \mathrm{BASF})$ as the electrolyte. In order to evaluate the electrochemical lithiation of $\mathrm{V}_{2} \mathrm{O}_{3}\left(\mathrm{SO}_{4}\right)_{2}$ as a positive electrode, cells were cycled in a temperature-controlled environment at $30^{\circ} \mathrm{C}$ using a Mac Pile Bio Logic II system in galvanostatic mode. To determine the cycling performance a cell was cycled over different rates $(\mathrm{C} / 20$, $\mathrm{C} / 10, \mathrm{C} / 5, \mathrm{C} / 2$ and C) at $30{ }^{\circ} \mathrm{C}$ using a Maccor Series 4200 system.

To understand the $\mathrm{Li}^{+}$insertion/extraction in $\mathrm{V}_{2} \mathrm{O}_{3}\left(\mathrm{SO}_{4}\right)_{2}$, multiple cells were discharged at a rate of $\mathrm{C} / 20$ to various states of discharge and charge. The positive electrodes were recovered from the $\mathrm{V}_{2} \mathrm{O}_{3}\left(\mathrm{SO}_{4}\right)_{2} \| \mathrm{Li}$ cells after cycling, washed with dimethyl carbonate (DMC, Sigma Aldrich, $\geq 99 \%$ ) three times in an argon filled glovebox, and dried under vacuum overnight.

\section{Chemical lithiation}

Four chemical lithiation reactions were performed with $n$ butyllithium (1.6 $\mathrm{M}$ in hexanes, Sigma Aldrich) in an argon filled glovebox at room temperature. $\mathrm{V}_{2} \mathrm{O}_{3}\left(\mathrm{SO}_{4}\right)_{2}(1.46 \mathrm{mmol})$ was dispersed in $n$-hexanes (Sigma Aldrich, 95\%, $\leq 20 \mathrm{~mL}$ ) and four different amounts of $n$-butyllithium were added, as detailed in Table 1 . The dispersions were stirred continuously for two weeks. The products were filtered, washed with $n$ hexanes, dried under vacuum and handled in an argon filled glovebox.

\section{Materials characterisation}

The pristine phase, $\mathrm{V}_{2} \mathrm{O}_{3}\left(\mathrm{SO}_{4}\right)_{2}$, and lithiated samples were examined using inductively coupled plasma optical emission spectroscopy (ICP-OES) analysis, powder X-ray diffraction (PXRD), neutron powder diffraction (NPD), X-ray absorption spectroscopy (XAS) and infrared (IR) spectroscopy, optical microscopy and scanning electron microscopy (SEM).

ICP-OES analysis was performed on the chemically lithiated samples using a Thermo Fisher Scientific ICP-OES iCAP 6000. Standards were prepared for lithium by diluting concentrated commercial ICP-OES standards to four different concentrations. The chemically lithiated samples were dissolved using aqua regia (solution of nitric acid and hydrochloric acid at a $1: 3$ ratio by volume).

Laboratory PXRD patterns were collected on a PANanalytical Empyrean diffractometer, using $\mathrm{Mo}-\mathrm{K}_{1,2}$ radiation $(\lambda=0.7107$ $\AA$ ) with a $\operatorname{Zr} \beta$-filter and X'celerator detector. Data were collected in the $2 \theta$ range, $3.5-35.0^{\circ}$ over $16 \mathrm{~h}$ per scan with a step size of $0.0167^{\circ}$, in capillaries at room temperature. Samples were loaded into glass capillaries $(0.7 \mathrm{~mm}$ diameter) in an argon filled glovebox. An NPD pattern was obtained on the GEM diffractometer at the ISIS Neutron and Muon Source, UK. The powdered sample was loaded into a $8 \mathrm{~mm}$ vanadium can under argon and sealed using an indium wire and the measurement was made under ambient conditions over $1 \mathrm{~h}$. Diffraction data were analysed using the Rietveld method using the general structural analysis system (GSAS) and its associated graphical user interface program (EXPGUI). ${ }^{\mathbf{2 4 , 2 5}}$

Vanadium K-edge (5.4651 keV) X-ray absorption spectra were acquired in transmission on B18 beamline at Diamond Light Source, UK. The powdered samples ( $8 \mathrm{mg}$ of active material)

Table 1 Summary of the chemical lithiation reactions

\begin{tabular}{llll}
\hline & \multicolumn{3}{c}{$n$-Butyllithium } \\
\cline { 3 - 4 } $\mathrm{V}_{2} \mathrm{O}_{3}\left(\mathrm{SO}_{4}\right)_{2} / \mathrm{mmol}$ & $n$-Hexane/mL & Moles $/ \mathrm{mmol}$ & Volume $/ \mathrm{mL}$ \\
\hline & & & \\
1.46 & 10 & 1.46 & 0.91 \\
1.46 & 10 & 2.92 & 1.83 \\
1.46 & 20 & 5.85 & 3.65 \\
1.46 & 20 & 11.70 & 7.30
\end{tabular}


were ground for $30 \mathrm{~min}$ with cellulose $(150 \mathrm{mg})$ and pressed into $13 \mathrm{~mm}$ diameter pellets, and then sealed into aluminium bags in an argon filled glovebox. XAS spectra of the vanadium metal foil were acquired simultaneously with the experimental samples. All spectra were acquired in triplicate for each sample. XAS spectra were aligned, merged and normalised using the software program Athena and EXAFS spectra were fitted using the program Artemis. ${ }^{26,27}$

An IRAffinity-1 Shimadzu Fourier transform IR spectrometer was used to obtain IR spectra. The powdered samples were placed directly onto the diamond crystal and IR spectra collected at room temperature between 4000 and $400 \mathrm{~cm}^{-1}$. Optical microscopy images were collected using a Meiji Techno microscope fitted with a Canon PowerShot G6 digital camera. A JEOL JSM-5600 SEM fitted with a tungsten filament electron source and a secondary electron detector were used to examine the morphology of the samples.
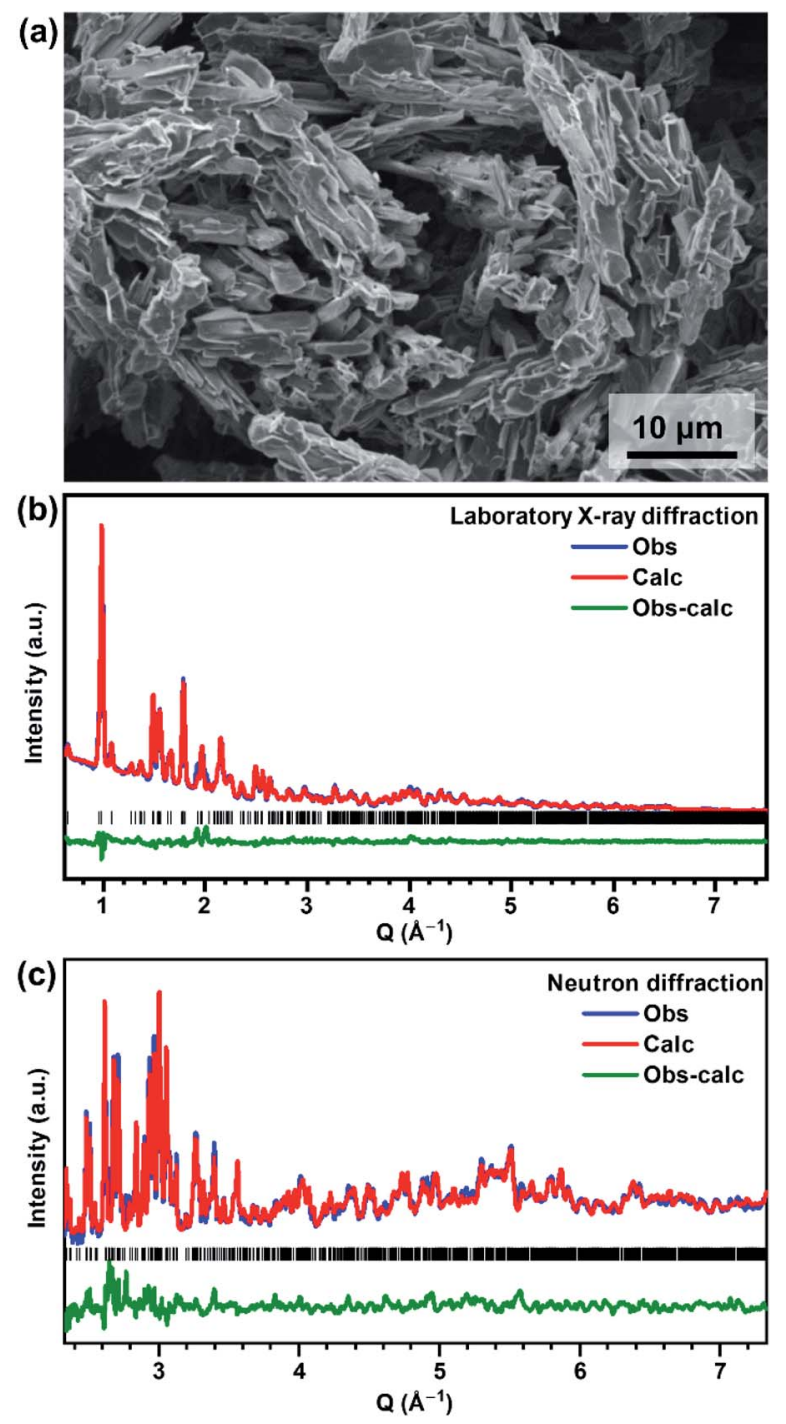

Fig. 1 (a) SEM micrograph of $\mathrm{V}_{2} \mathrm{O}_{3}\left(\mathrm{SO}_{4}\right)_{2}$, (b) laboratory X-ray diffraction Rietveld fit and (c) neutron diffraction Rietveld fit for $\mathrm{V}_{2} \mathrm{O}_{3}\left(\mathrm{SO}_{4}\right)_{2}$ using the structural model published by Richter et al. as the starting model. ${ }^{23}$

\section{Results and discussion}

Characterisation of $\mathrm{V}_{2} \mathrm{O}_{3}\left(\mathrm{SO}_{4}\right)_{2}$

$\mathrm{V}_{2} \mathrm{O}_{3}\left(\mathrm{SO}_{4}\right)_{2}$ was successfully prepared using a lower temperature of $140{ }^{\circ} \mathrm{C}$, compared to the previously reported synthesis temperature of $180{ }^{\circ} \mathrm{C} .{ }^{23}$ The SEM micrograph of $\mathrm{V}_{2} \mathrm{O}_{3}\left(\mathrm{SO}_{4}\right)_{2}$, shown in Fig. 1(a) reveals a homogeneous morphology consisting of acicular crystallites.

$\mathrm{V}_{2} \mathrm{O}_{3}\left(\mathrm{SO}_{4}\right)_{2}$ can be indexed to a monoclinic unit cell with the space group $P 2_{1} / a$ and unit cell parameters $a=9.464(12) \AA$, $b=$ 8.908(13) $\mathrm{A}, c=9.939(12) \AA, \beta=104.732(4)^{\circ}$. All peaks were indexed and the unit cell parameters correspond well with those reported by Richter et al. ${ }^{23}$ A Rietveld refinement was performed using the structural model published by Richter et al. ${ }^{23}$ The Rietveld fits of the PXRD and NPD data are shown in Fig. 1(b) and (c), respectively, and the atomic coordinates and isotropic thermal parameters are given in the ESI, Table $\mathrm{S} 1 . \dagger$

The structure of $\mathrm{V}_{2} \mathrm{O}_{3}\left(\mathrm{SO}_{4}\right)_{2}$ is illustrated in Fig. 2. $\mathrm{V}_{2} \mathrm{O}_{3}\left(\mathrm{SO}_{4}\right)_{2}$ is made up of pairs of vanadium octahedra linked by a bridging oxygen atom and two corner-sharing $\mathrm{SO}_{4}$ tetrahedra, forming
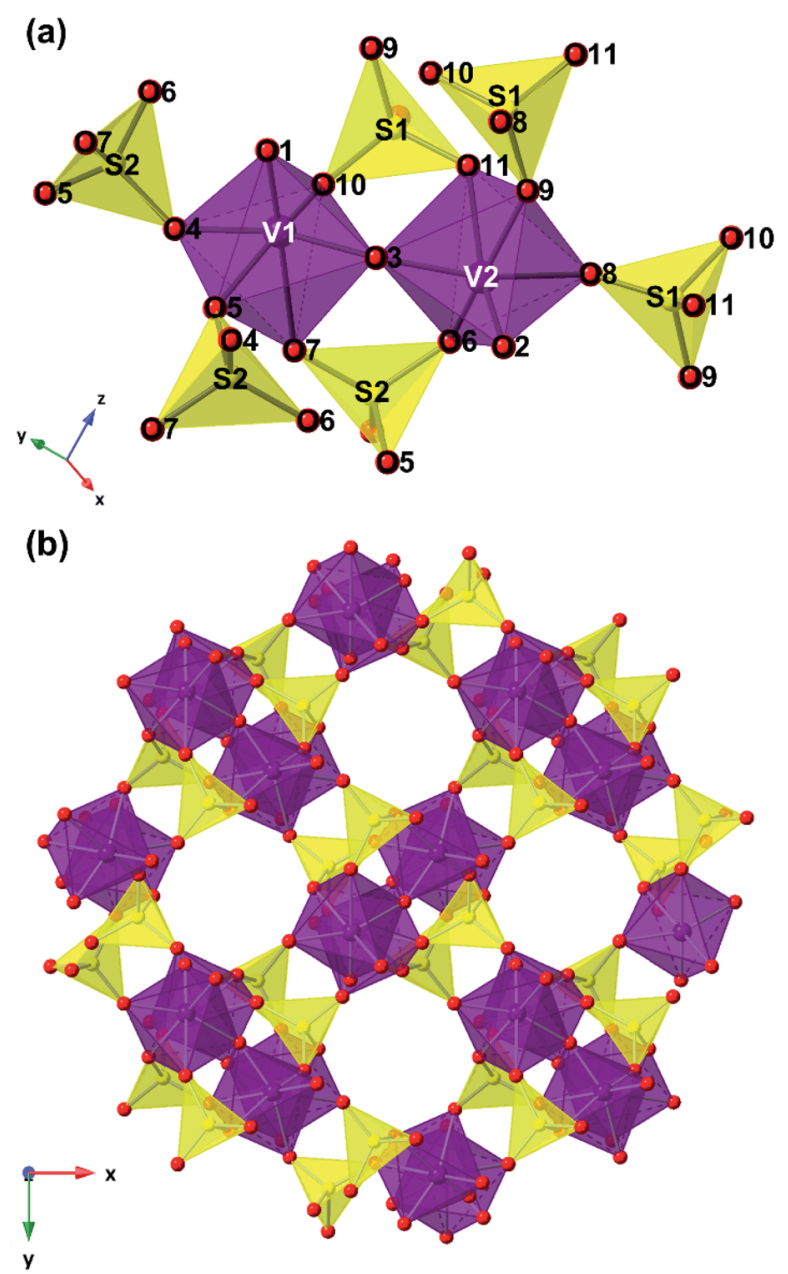

Fig. 2 Structural model of $\mathrm{V}_{2} \mathrm{O}_{3}\left(\mathrm{SO}_{4}\right)_{2}$ showing (a) the $\left[\mathrm{V}_{2} \mathrm{O}_{3}\right]^{4+}$ subunit made up of pairs of vanadium octahedra (purple polyhedra) linked to each other by a bridging oxygen atom (red spheres) and two bridging $\mathrm{SO}_{4}$ tetrahedra (yellow polyhedra) and (b) the open channels down the $c$-axis. 
the $\left[\mathrm{V}_{2} \mathrm{O}_{3}\right]^{4+}$ subunit which consists of the two species, $\left[\mathrm{V}(1) \mathrm{O}_{2}\right]^{+}$ and $[\mathrm{V}(2) \mathrm{O}]^{3+}$, as shown in Fig. 2(a). The corner sharing $\mathrm{VO}_{6}$ distorted octahedra and $\mathrm{SO}_{4}$ tetrahedra create a threedimensional network with open channels running down the $c$ axis as illustrated in Fig. 2(b). The VO bond lengths in $\mathrm{V}_{2} \mathrm{O}_{3}\left(\mathrm{SO}_{4}\right)_{2}$ are summarised in Table S2. $\dagger$

\section{Electrochemical lithiation}

The electrochemical $\mathrm{Li}^{+}$insertion/extraction process in $\mathrm{V}_{2} \mathrm{O}_{3}\left(\mathrm{SO}_{4}\right)_{2}$ was explored. Cells were cycled in galvanostatic mode between $4.20 \mathrm{~V}$ and $1.95 \mathrm{~V}$ at a rate of $\mathrm{C} / 20$, starting on discharge. The galvanostatic discharge-charge curves for the first, second, third and fifth cycles and the derivative $\mathrm{d} x / \mathrm{d} V$ curve of the first cycle are shown in Fig. 3(a) and (b), respectively. The galvanostatic curve (Fig. 3(a)) reveals four sloping plateaux on discharge and charge, and approximately $2.0 \mathrm{Li}^{+}\left(160 \mathrm{~mA} \mathrm{~h} \mathrm{~g}{ }^{-1}\right)$ were inserted on the first discharge, hence the average vanadium oxidation state reached +4.00 . The $\mathrm{d} x / \mathrm{d} V$ curve (Fig. $3(\mathrm{~b})$ ) shows four redox peaks centred about $4.09 \mathrm{~V}, 3.25 \mathrm{~V}, 2.83 \mathrm{~V}$ and $2.23 \mathrm{~V}$ $v s . \mathrm{Li}^{+} / \mathrm{Li}^{0}$. The intensities of the reduction peaks are greater than those of the oxidation peaks, suggesting that not all the $\mathrm{Li}^{+}$that was inserted could be extracted. As for the redox processes centred about $3.25 \mathrm{~V}$, the $\mathrm{d} x / \mathrm{d} V$ curve shows two reduction peaks at $3.23 \mathrm{~V}$ and $3.14 \mathrm{~V}$ and two oxidation peaks at $3.15 \mathrm{~V}$ and $3.11 \mathrm{~V}$. These peaks suggest charge-ordering of the vanadium atoms or vacancy-ordering of $\mathrm{Li}^{+}$which has been reported for $\mathrm{Li}_{x} \mathrm{Mn}_{2} \mathrm{O}_{4}$ among other systems. ${ }^{28-30}$ Upon subsequent cycling, the electrode can reversibly insert approximately $1.5 \mathrm{Li}^{+}$, leading to a reversible capacity of approximately $120 \mathrm{~mA} \mathrm{~h} \mathrm{~g}{ }^{-1}$, which progressively decays upon cycling. Additionally, a cell was cycled in potentiostatic mode at a slow rate of $5.6 \mu \mathrm{V} \mathrm{s}^{-1}$ between $4.20 \mathrm{~V}$ and $1.95 \mathrm{~V}$. The voltammogram is shown in Fig. $\mathrm{S} 1 \dagger$ and corresponds well with the $\mathrm{d} x / \mathrm{d} V$ curve obtained from galvanostatic cycling (Fig. 3(b)), showing the same four redox processes occurring at $4.09 \mathrm{~V}, 3.25 \mathrm{~V}, 2.83 \mathrm{~V}$ and $2.23 \mathrm{~V}$ vs. $\mathrm{Li}^{+} / \mathrm{Li}^{0}$.

Fig. 3(c) shows the specific capacities over different C-rates $(\mathrm{C} / 20, \mathrm{C} / 10, \mathrm{C} / 5, \mathrm{C} / 2$ and $\mathrm{C})$. The first cycle at $\mathrm{C} / 20$ shows some irreversible capacity (coulombic efficiency of $90 \%$ ) but subsequent cycles at $\mathrm{C} / 20$ show a lower capacity but greater coulombic efficiency of $97 \%$. The discharge and charge capacities decreased to $25 \mathrm{~mA} \mathrm{~h} \mathrm{~g}^{-1}$ at $1 \mathrm{C}$. After cycling at the faster C-rates a reasonable capacity ( $110 \mathrm{~mA} \mathrm{~h} \mathrm{~g}{ }^{-1}$, coulombic efficiency of $92 \%$ ) was reached by the $27^{\text {th }}$ cycle at $\mathrm{C} / 20$, suggesting that $\mathrm{V}_{2} \mathrm{O}_{3}\left(\mathrm{SO}_{4}\right)_{2}$ did not degrade after cycling at faster rates. The first cycle of each Crate shows greater irreversible capacity than the subsequent cycles, indicating that the redox processes are rate dependent.

To understand the electrochemical $\mathrm{Li}^{+}$insertion/extraction in $\mathrm{V}_{2} \mathrm{O}_{3}\left(\mathrm{SO}_{4}\right)_{2}$ multiple cells of $\mathrm{V}_{2} \mathrm{O}_{3}\left(\mathrm{SO}_{4}\right)_{2} \| \mathrm{Li}$ were discharged to the potentials $3.50 \mathrm{~V}, 2.95 \mathrm{~V}, 2.40 \mathrm{~V}$ and $1.95 \mathrm{~V}$ and charged to $4.00 \mathrm{~V}$. These potentials were selected because they correspond to the inflection points observed between the plateaux in the voltage profile and $\mathrm{d} x / \mathrm{d} V$ curves (Figure S2 $\dagger$ ).

\section{Chemical lithiation}

ICP-OES data were collected to determine the amount of lithium in the chemically lithiated samples and their
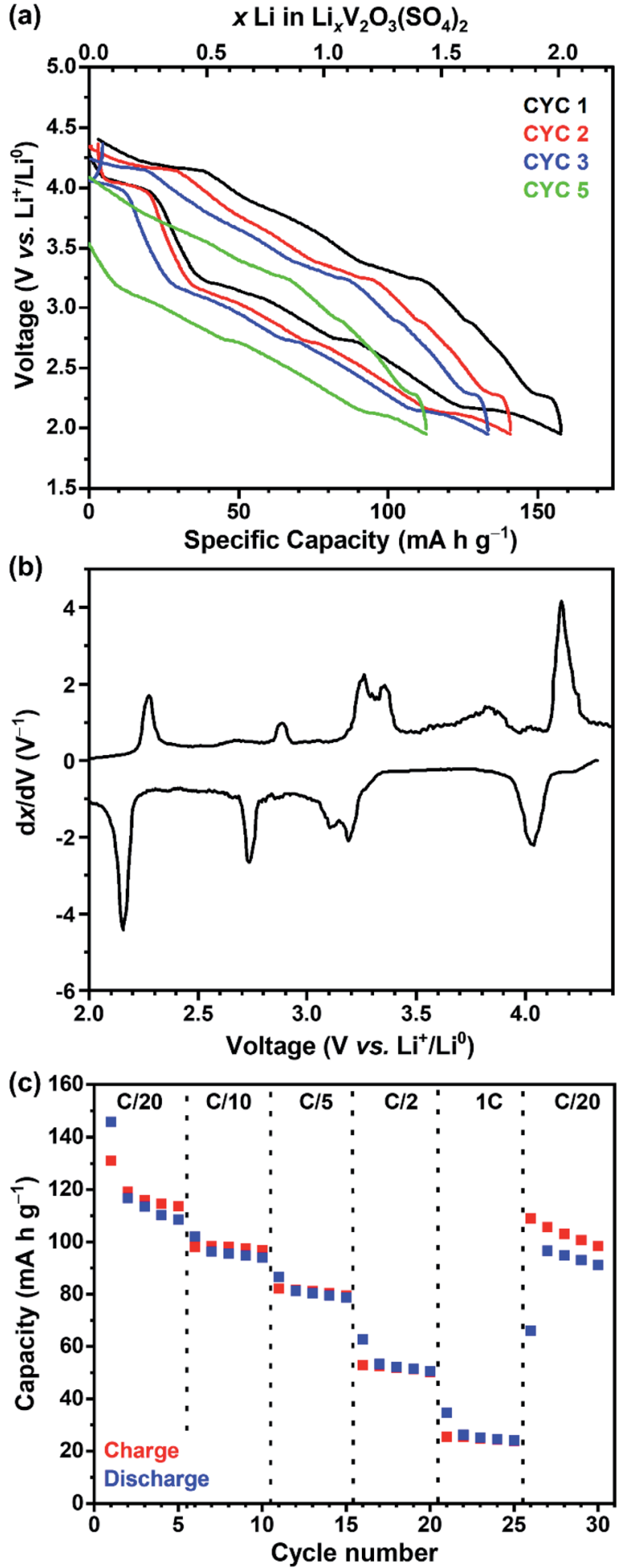

Fig. 3 (a) $\mathrm{V}_{2} \mathrm{O}_{3}\left(\mathrm{SO}_{4}\right)_{2} \|$ Li cell cycled at a rate of $\mathrm{C} / 20$ between $4.20 \mathrm{~V}$ and $1.95 \mathrm{~V}$ showing the voltage-capacity curve for the first (black), second (red), third (blue) and fifth cycles (green), (b) the derivative $\mathrm{d} x / \mathrm{d} V$ curve of the first cycle and (c) the specific capacity versus different $\mathrm{C}$-rates $(\mathrm{C} / 2 \mathrm{O}, \mathrm{C} / 10, \mathrm{C} / 5, \mathrm{C} / 2,1 \mathrm{C})$ of $\mathrm{V}_{2} \mathrm{O}_{3}\left(\mathrm{SO}_{4}\right)_{2}$ cycled between $4.20 \mathrm{~V}$ and $1.95 \mathrm{~V}$ vs. $\mathrm{Li}^{+} / \mathrm{Li}^{0}$. 
Table 2 Lithium content in the chemically lithiated samples obtained from ICP-OES analysis

\begin{tabular}{|c|c|c|c|}
\hline Moles of $n$-butyllithium/mol & $\begin{array}{l}x \mathrm{Li} \\
\text { from ICP-OES analysis }\end{array}$ & Experimental composition & $\begin{array}{l}\text { Vanadium oxidation } \\
\text { state based on composition }\end{array}$ \\
\hline 0.00 & $0.00(0)$ & $\mathrm{V}_{2} \mathrm{O}_{3}\left(\mathrm{SO}_{4}\right)_{2}$ & $+5.00(0)$ \\
\hline 1.46 & $0.97(2)$ & $\mathrm{Li}_{0.97} \mathrm{~V}_{2} \mathrm{O}_{3}\left(\mathrm{SO}_{4}\right)_{2}$ & $+4.52(1)$ \\
\hline 2.92 & $1.64(16)$ & $\mathrm{Li}_{1.64} \mathrm{~V}_{2} \mathrm{O}_{3}\left(\mathrm{SO}_{4}\right)_{2}$ & $+4.18(8)$ \\
\hline 5.85 & $2.47(3)$ & $\mathrm{Li}_{2.47} \mathrm{~V}_{2} \mathrm{O}_{3}\left(\mathrm{SO}_{4}\right)_{2}$ & $+3.77(2)$ \\
\hline 11.70 & $3.97(5)$ & $\mathrm{Li}_{3.97} \mathrm{~V}_{2} \mathrm{O}_{3}\left(\mathrm{SO}_{4}\right)_{2}$ & $+3.02(3)$ \\
\hline
\end{tabular}

compositions are given in Table 2 . The oxidation states of vanadium are also given in Table 2 . These were calculated based on charge balance considerations, assuming the oxidation states of lithium and oxygen are +1 and -2 , respectively, and that all the lithium present in the sample was incorporated into $\mathrm{V}_{2} \mathrm{O}_{3}\left(\mathrm{SO}_{4}\right)_{2}$.

Chemical lithiation of $\mathrm{V}_{2} \mathrm{O}_{3}\left(\mathrm{SO}_{4}\right)_{2}$ resulted in colour changes as shown in Fig. 4, from the yellow pristine phase, $\mathrm{V}_{2} \mathrm{O}_{3}\left(\mathrm{SO}_{4}\right)_{2}$, to green $\mathrm{Li}_{0.97} \mathrm{~V}_{2} \mathrm{O}_{3}\left(\mathrm{SO}_{4}\right)_{2}$, darker green $\mathrm{Li}_{1.64} \mathrm{~V}_{2} \mathrm{O}_{3}\left(\mathrm{SO}_{4}\right)_{2}$ and $\mathrm{Li}_{2.47} \mathrm{~V}_{2} \mathrm{O}_{3}\left(\mathrm{SO}_{4}\right)_{2}$, to dark blue $\mathrm{Li}_{3.97} \mathrm{~V}_{2} \mathrm{O}_{3}\left(\mathrm{SO}_{4}\right)_{2}$. Optical images, also presented in Fig. 4, show the samples getting darker in colour with increasing $\mathrm{Li}^{+}$content. These colour changes are consistent with changes in the vanadium oxidation state as discussed below. SEM micrographs of the chemically lithiated samples, shown in Fig. 4, show some needle-shaped crystallites which are consistent with $\mathrm{V}_{2} \mathrm{O}_{3}\left(\mathrm{SO}_{4}\right)_{2}$ (Fig. 1(a)), suggesting that $\mathrm{Li}^{+}$insertion did not cause the morphology of $\mathrm{V}_{2} \mathrm{O}_{3}\left(\mathrm{SO}_{4}\right)_{2}$ to break down completely.

\section{Vanadium oxidation state of $\mathrm{Li}_{x} \mathrm{~V}_{2} \mathrm{O}_{3}\left(\mathrm{SO}_{4}\right)_{2}$}

To confirm that the $\mathrm{Li}^{+}$insertion was accompanied by a change in the vanadium oxidation state, vanadium K-edge XAS measurements were performed. Data were collected on $\mathrm{V}_{2} \mathrm{O}_{3}\left(\mathrm{SO}_{4}\right)_{2}$ electrodes at various states of discharge and charge, the chemically lithiated phases, as well as vanadium foil, $\mathrm{V}_{2} \mathrm{O}_{3}$, VOSO $_{4} \cdot 3 \mathrm{H}_{2} \mathrm{O}$ and $\mathrm{V}_{2} \mathrm{O}_{5}$ reference compounds with vanadium formal oxidation states of $0,+3,+4$, and +5 , respectively. The XANES spectra for $\mathrm{V}_{2} \mathrm{O}_{5}, \mathrm{VOSO}_{4} \cdot 3 \mathrm{H}_{2} \mathrm{O}$ and $\mathrm{V}_{2} \mathrm{O}_{3}$ reference compounds, the pristine phase, $\mathrm{V}_{2} \mathrm{O}_{3}\left(\mathrm{SO}_{4}\right)_{2}$ and the electrochemically lithiated samples are compared in Fig. 5(a) and the chemically lithiated samples are shown in Fig. 5(b).

Fig. 5(a) and (b) show the intensity of the pre-edge peak decreases with increasing $\mathrm{Li}^{+}$content. The intensity of the preedge peak is correlated to the size of the $\mathrm{VO}_{x}$ coordination sphere which is $55 \%$ of the total intensity. ${ }^{31}$ This suggests that the shorter, vanadyl $\mathrm{V}=\mathrm{O}$ bonds increase in length and thereby the $\mathrm{VO}_{6}$ octahedra become more symmetrical.

This is consistent with a $\mathrm{V}^{5+}$ to $\mathrm{V}^{4+}$ transition for the electrode discharged to $1.95 \mathrm{~V}$ and a transition to $\mathrm{V}^{3+}$ for $\mathrm{Li}_{3.97} \mathrm{~V}_{2} \mathrm{O}_{3}\left(\mathrm{SO}_{4}\right)_{2} \cdot{ }^{31,32}$

Furthermore, Fig. 5(a) and (b) reveal a small difference in the edge energies for $\mathrm{V}_{2} \mathrm{O}_{5}$ and $\mathrm{V}_{2} \mathrm{O}_{3}\left(\mathrm{SO}_{4}\right)_{2}$, despite these materials having the same oxidation state because the edge energy of a material is also influenced by differences in coordination

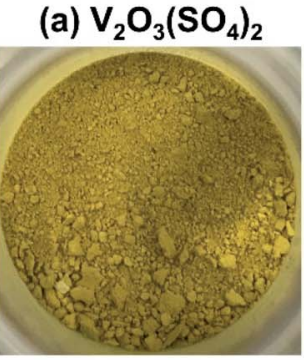

(b) $\mathrm{Li}_{0.97} \mathrm{~V}_{2} \mathrm{O}_{3}\left(\mathrm{SO}_{4}\right)_{2}$
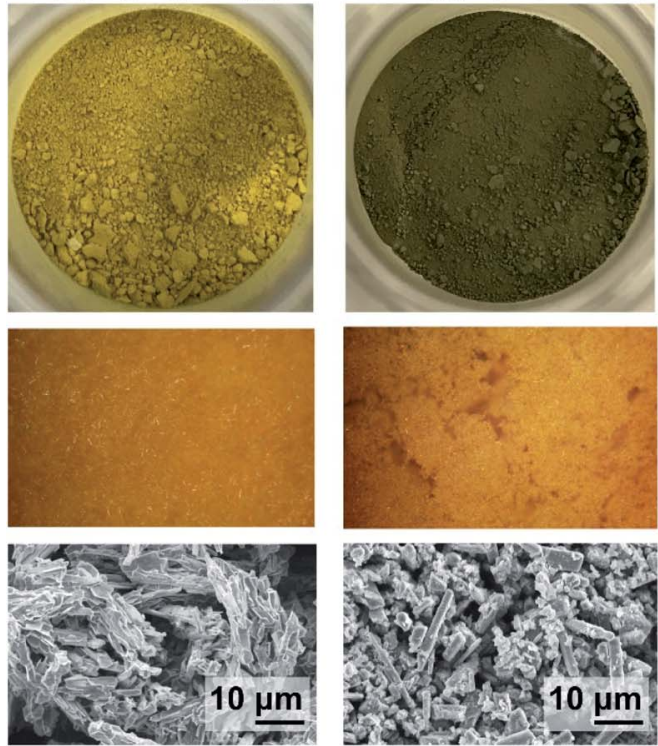

(c) $\mathrm{Li}_{1.64} \mathrm{~V}_{2} \mathrm{O}_{3}\left(\mathrm{SO}_{4}\right)_{2}$
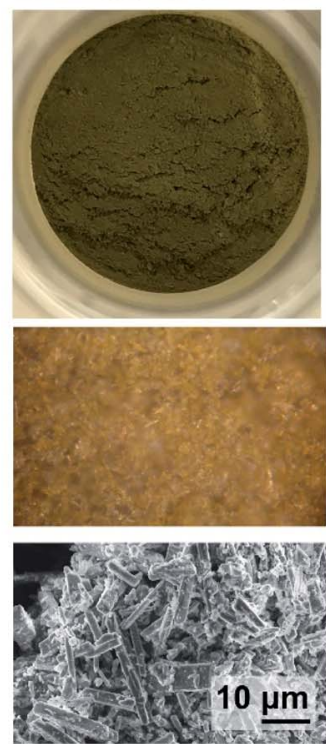

(d) $\mathrm{Li}_{2.47} \mathrm{~V}_{2} \mathrm{O}_{3}\left(\mathrm{SO}_{4}\right)_{2}$

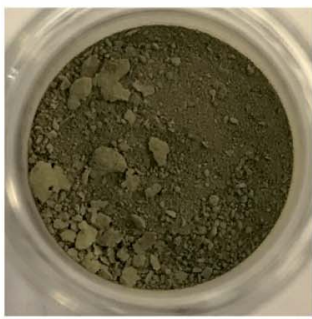

(e) $\mathrm{Li}_{3.97} \mathrm{~V}_{2} \mathrm{O}_{3}\left(\mathrm{SO}_{4}\right)_{2}$
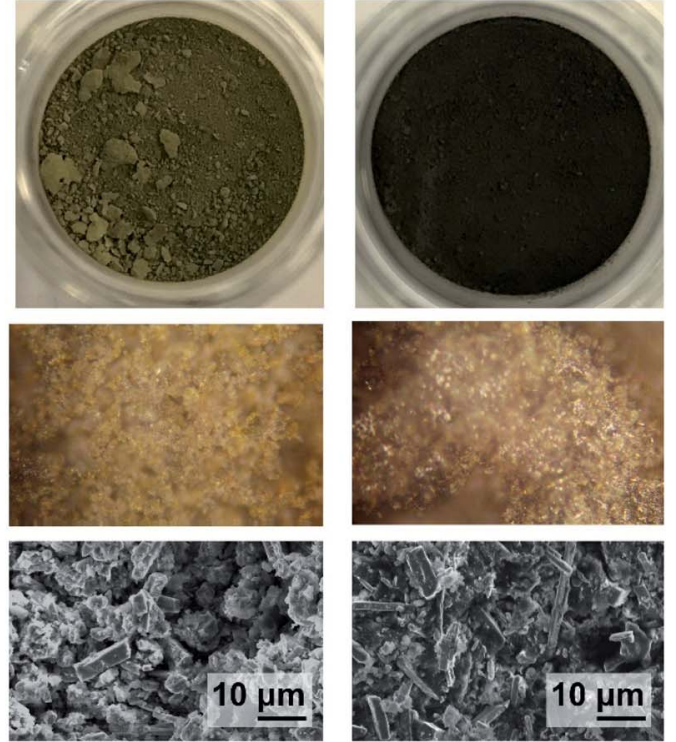

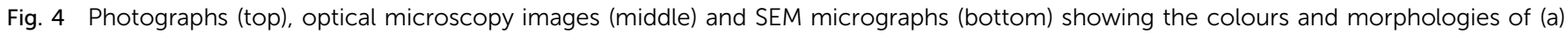
$\mathrm{V}_{2} \mathrm{O}_{3}\left(\mathrm{SO}_{4}\right)_{2}$, (b) $\mathrm{Li}_{0.97} \mathrm{~V}_{2} \mathrm{O}_{3}\left(\mathrm{SO}_{4}\right)_{2}$, (c) $\mathrm{Li}_{1.64} \mathrm{~V}_{2} \mathrm{O}_{3}\left(\mathrm{SO}_{4}\right)_{2}$, (d) $\mathrm{Li}_{2.47} \mathrm{~V}_{2} \mathrm{O}_{3}\left(\mathrm{SO}_{4}\right)_{2}$ and (e) $\mathrm{Li}_{3.97} \mathrm{~V}_{2} \mathrm{O}_{3}\left(\mathrm{SO}_{4}\right)_{2}$. 

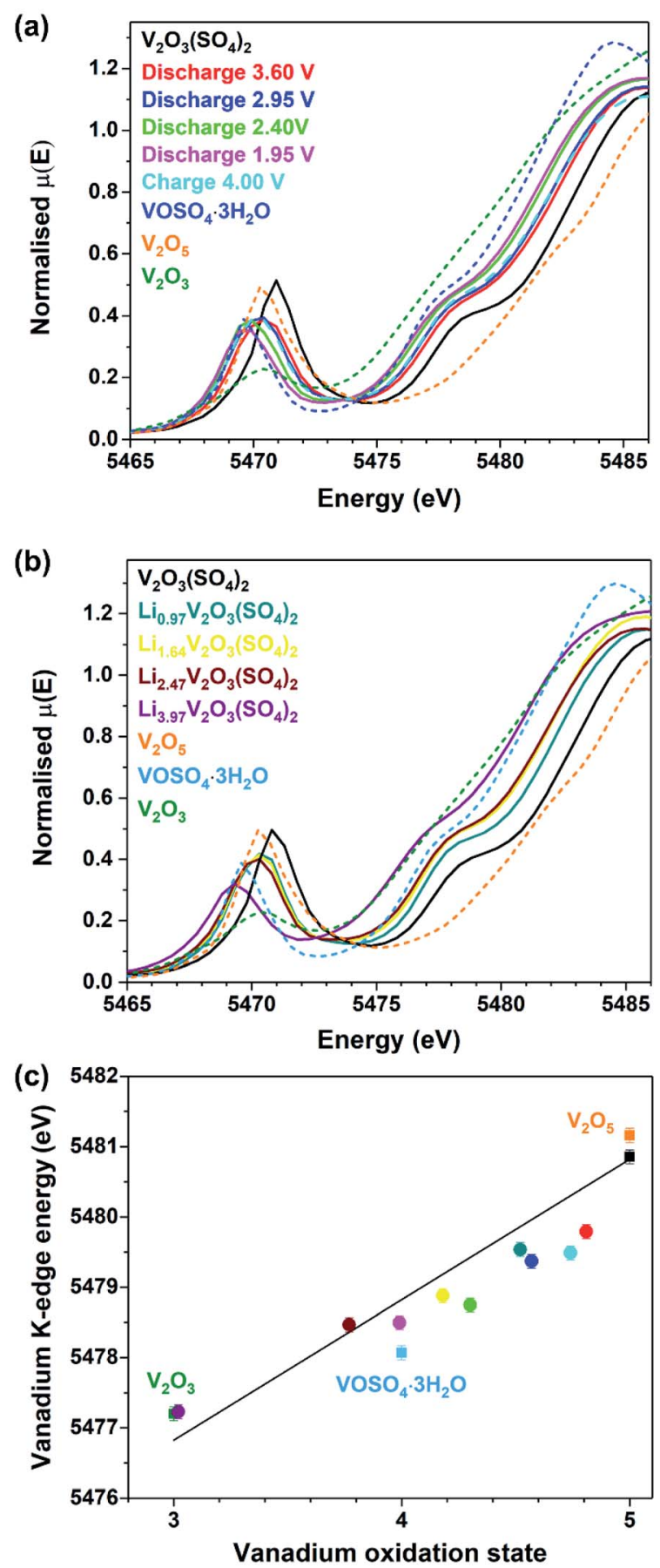

Fig. 5 Vanadium K-edge XANES data showing (a) normalised spectra for the $\mathrm{V}_{2} \mathrm{O}_{3}\left(\mathrm{SO}_{4}\right)_{2}$ electrodes at various states of discharge and charge compared to the reference materials, $\mathrm{V}_{2} \mathrm{O}_{5}, \mathrm{VOSO}_{4} \cdot 3 \mathrm{H}_{2} \mathrm{O}$ and $\mathrm{V}_{2} \mathrm{O}_{3}$, (b) normalised spectra for the chemically lithiated $\mathrm{V}_{2} \mathrm{O}_{3}\left(\mathrm{SO}_{4}\right)_{2}$ samples compared to the reference materials and (c) vanadium $\mathrm{K}$-edge energy (at half-height) as a function of oxidation state.

number and electronegativity of the ligands. ${ }^{31}$ The edge positions of the lithiated phases shift progressively to lower energies with increasing $\mathrm{Li}^{+}$content relative to $\mathrm{V}_{2} \mathrm{O}_{3}\left(\mathrm{SO}_{4}\right)_{2}$. The edge energy of the $\mathrm{V}_{2} \mathrm{O}_{3}\left(\mathrm{SO}_{4}\right)_{2}$ electrode discharged to $1.95 \mathrm{~V}$ is similar to the reference material, $\operatorname{VOSO}_{4} \cdot 3 \mathrm{H}_{2} \mathrm{O}$, suggesting that approximately $2.0 \mathrm{~mol} \mathrm{Li}$ per mol $\mathrm{V}_{2} \mathrm{O}_{3}\left(\mathrm{SO}_{4}\right)_{2}$ were inserted electrochemically, which is in agreement with the electrochemical data (Fig. 3). The edge energy of the $\mathrm{V}_{2} \mathrm{O}_{3}\left(\mathrm{SO}_{4}\right)_{2}$ electrode charged to $4.00 \mathrm{~V}$ was shifted to a higher energy relative to the electrode discharged to $1.95 \mathrm{~V}$, suggesting an increase in the vanadium oxidation state upon $\mathrm{Li}^{+}$extraction, as expected. ${ }^{33}$ However, the electrode charged to $4.00 \mathrm{~V}$ shows a similar edge energy to the electrode discharged to $3.60 \mathrm{~V}$, implying that the electrochemical process was partially irreversible.

The edge energies of the chemically lithiated materials also shift to lower energies with increasing $\mathrm{Li}^{+}$content, suggesting $\mathrm{Li}^{+}$was incorporated into the structure of $\mathrm{V}_{2} \mathrm{O}_{3}\left(\mathrm{SO}_{4}\right)_{2}$ in agreement with the colour changes observed (Fig. 4). $\mathrm{Li}_{3.97} \mathrm{~V}_{2} \mathrm{O}_{3}\left(\mathrm{SO}_{4}\right)_{2}$ has a very similar edge energy to $\mathrm{V}_{2} \mathrm{O}_{3}$, implying approximately $4.0 \mathrm{Li}^{+}$per mol was incorporated which agrees with the ICP-OES analysis for this phase. The absorption edge energies for the reference compounds $\mathrm{V}_{2} \mathrm{O}_{3}, \mathrm{VOSO}_{4} \cdot 3 \mathrm{H}_{2} \mathrm{O}, \mathrm{V}_{2} \mathrm{O}_{5}, \mathrm{~V}_{2} \mathrm{O}_{3}\left(\mathrm{SO}_{4}\right)_{2}$ are plotted in Fig. 5(c); these edge energies exhibit an essentially linear relationship with formal oxidation state. The edge energies of the reference materials are similar to those previously reported, thus a comparable linear relationship was obtained. ${ }^{31,33,34}$ To determine if the energy shifts of the absorption energies are consistent with the $\mathrm{Li}^{+}$content, the energies of the absorption edges taken at half-height of the normalised spectra, were plotted against vanadium oxidation state. The $\mathrm{Li}^{+}$content was derived from the electrochemical data for the electrochemically lithiated samples and ICP-OES analysis for the chemically lithiated samples. The average oxidation state of vanadium was calculated from the composition by assuming that the oxidation states of lithium and oxygen were +1 and -2 , respectively. The edge energies for the electrochemically lithiated samples suggest that the vanadium oxidation states are comparable to those estimated based on the electrochemical data. Similar edge shifts have also been reported for other vanadium-based electrodes, including for example $\mathrm{Li}_{x} \mathrm{~V}_{2} \mathrm{O}_{5}$, $\mathrm{LiVOPO}_{4}$ and $\mathrm{Na}_{x} \mathrm{VPO}_{4.8} \mathrm{~F}_{0.7} \cdot{ }^{14,32,33,35,36}$ As for $\mathrm{Li}_{3.97} \mathrm{~V}_{2} \mathrm{O}_{3}\left(\mathrm{SO}_{4}\right)_{2}$, its edge energy shows $4.0 \mathrm{Li}^{+}$per mol of $\mathrm{V}_{2} \mathrm{O}_{3}\left(\mathrm{SO}_{4}\right)_{2}$ were inserted, thereby demonstrating that two additional mol of $\mathrm{Li}$ per $\mathrm{mol}$ of $\mathrm{V}_{2} \mathrm{O}_{3}\left(\mathrm{SO}_{4}\right)_{2}$ can be inserted chemically.

The experimental compositions and vanadium oxidation states for the lithiated samples are given in Table 3. The experimental compositions for the $\mathrm{V}_{2} \mathrm{O}_{3}\left(\mathrm{SO}_{4}\right)_{2}$ electrodes were estimated based on the electrochemical data (Fig. 3(a)), assuming the oxidation states of lithium and oxygen were +1 and -2 , respectively. The compositions of the chemically lithiated samples were obtained from ICP-OES analysis. The vanadium oxidation states of the lithiated samples are also given based on the compositions and the absorption edge energy, at half-height of the normalised XANES spectra.

In addition to using XANES analysis to confirm the change in vanadium oxidation state, IR spectra were collected. The IR spectra of $\mathrm{V}_{2} \mathrm{O}_{3}\left(\mathrm{SO}_{4}\right)_{2}$, the $\mathrm{V}_{2} \mathrm{O}_{3}\left(\mathrm{SO}_{4}\right)_{2}$ electrodes and the chemically lithiated phases are presented in Fig. 6(a) and (b), respectively. The IR spectrum of $\mathrm{V}_{2} \mathrm{O}_{3}\left(\mathrm{SO}_{4}\right)_{2}$ exhibits absorption bands previously reported for $\mathrm{V}_{2} \mathrm{O}_{3}\left(\mathrm{SO}_{4}\right)_{2}$, including the short vanadyl bond $\left(993 \mathrm{~cm}^{-1}\right)$, intermediate $\mathrm{V}-\mathrm{O}$ bond $\left(948 \mathrm{~cm}^{-1}\right)$ and $\mathrm{V}-\mathrm{O}-\mathrm{V}$ bond $\left(770 \mathrm{~cm}^{-1}\right) \cdot{ }^{23,37}$ It was expected that the 
Table 3 Summary of the experimental compositions of $\mathrm{Li}_{x} \mathrm{~V}_{2} \mathrm{O}_{3}\left(\mathrm{SO}_{4}\right)_{2}$ materials and their vanadium oxidation states. The compositions of the electrochemically lithiated samples were estimated based on electrochemical data. The composition of the chemically lithiated samples were determined using ICP-OES analysis. The vanadium oxidation states are given based on the experimental compositions and the XANES data

\begin{tabular}{lllll}
\hline Sample & $\begin{array}{l}\text { Composition based } \\
\text { on experimental data }\end{array}$ & $\begin{array}{l}\text { Vanadium oxidation } \\
\text { state based on composition }\end{array}$ & Edge energy/eV & $\begin{array}{l}\text { Vanadium oxidation } \\
\text { state based on edge energy }\end{array}$ \\
\hline $\mathrm{V}_{2} \mathrm{O}_{3}\left(\mathrm{SO}_{4}\right)_{2}$ & $\mathrm{~V}_{2} \mathrm{O}_{3}\left(\mathrm{SO}_{4}\right)_{2}$ & +5.00 & $5480.9(1)$ & $+5.04(5)$ \\
Discharge $3.60 \mathrm{~V}$ & $\mathrm{Li}_{0.39} \mathrm{~V}_{2} \mathrm{O}_{3}\left(\mathrm{SO}_{4}\right)_{2}$ & +4.81 & $5479.8(1)$ & $+4.48(5)$ \\
Discharge $2.95 \mathrm{~V}$ & $\mathrm{Li}_{0.89} \mathrm{~V}_{2} \mathrm{O}_{3}\left(\mathrm{SO}_{4}\right)_{2}$ & +4.57 & $5479.4(1)$ & $+4.27(5)$ \\
Discharge $2.40 \mathrm{~V}$ & $\mathrm{Li}_{1.40} \mathrm{~V}_{2} \mathrm{O}_{3}\left(\mathrm{SO}_{4}\right)_{2}$ & +4.30 & $5478.8(1)$ & $+3.87(5)$ \\
Discharge $1.95 \mathrm{~V}$ & $\mathrm{Li}_{2.01} \mathrm{~V}_{2} \mathrm{O}_{3}\left(\mathrm{SO}_{4}\right)_{2}$ & +3.99 & $5478.5(1)$ & $+3.84(5)$ \\
Charge $4.00 \mathrm{~V}$ & $\mathrm{Li}_{0.53} \mathrm{~V}_{2} \mathrm{O}_{3}\left(\mathrm{SO}_{4}\right)_{2}$ & +4.74 & $5479.5(1)$ & $+4.33(5)$ \\
1.46 mmol $n \mathrm{BuLi}$ & $\mathrm{Li}_{0.97} \mathrm{~V}_{2} \mathrm{O}_{3}\left(\mathrm{SO}_{4}\right)_{2}$ & $+4.52(1)$ & $5479.5(1)$ & $+4.34(5)$ \\
$2.92 \mathrm{mmol} n \mathrm{BuLi}$ & $\mathrm{Li}_{1.64} \mathrm{~V}_{2} \mathrm{O}_{3}\left(\mathrm{SO}_{4}\right)_{2}$ & $+4.18(8)$ & $5478.9(1)$ & $+4.03(5)$ \\
$5.85 \mathrm{mmol} n \mathrm{BuLi}$ & $\mathrm{Li}_{2.47} \mathrm{~V}_{2} \mathrm{O}_{3}\left(\mathrm{SO}_{4}\right)_{2}$ & $+3.77(2)$ & $5477.2(1)$ & $+3.82(5)$ \\
$11.70 \mathrm{mmol} n \mathrm{BuLi}$ & $\mathrm{Li}_{3.97} \mathrm{~V}_{2} \mathrm{O}_{3}\left(\mathrm{SO}_{4}\right)_{2}$ & $+3.02(3)$ & & $+3.20(5)$
\end{tabular}

vanadium oxidation state should decrease with increasing $\mathrm{Li}^{+}$ content which is in agreement with the XANES analysis. As a result, one of the short $\mathrm{V}=\mathrm{O}$ bonds of the $\left[\mathrm{VO}_{2}\right]^{+}$species and

(a)

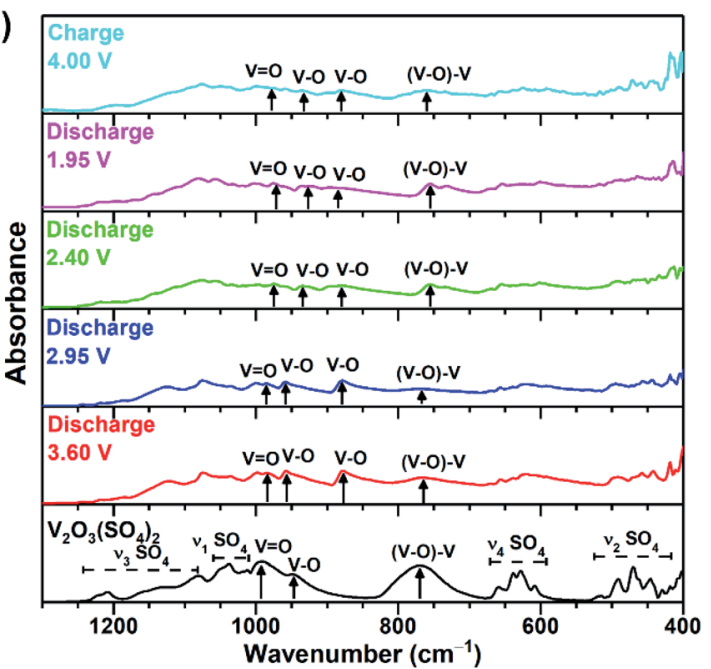

(b)

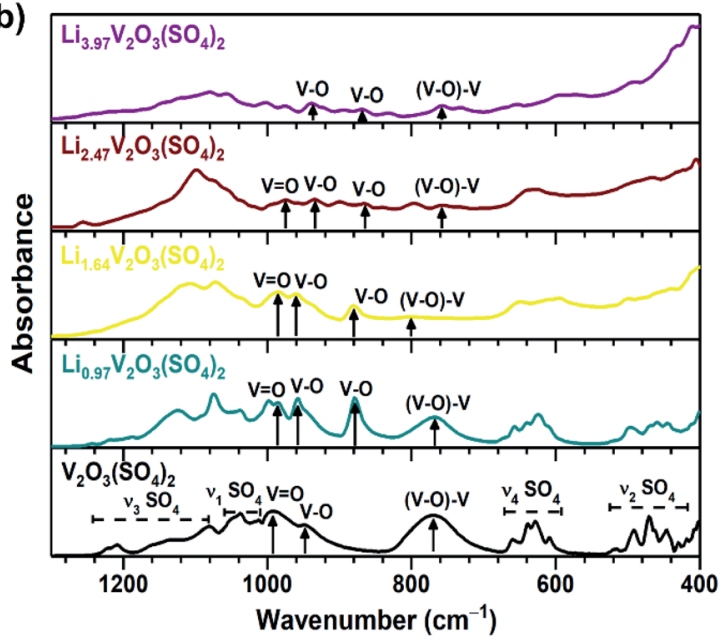

Fig. 6 IR spectra of (a) $\mathrm{V}_{2} \mathrm{O}_{3}\left(\mathrm{SO}_{4}\right)_{2}$ (black) and the $\mathrm{V}_{2} \mathrm{O}_{3}\left(\mathrm{SO}_{4}\right)_{2}$ electrode discharged to $3.60 \mathrm{~V}$ (red), discharged to $2.95 \mathrm{~V}$ (blue), discharged to $2.40 \mathrm{~V}$ (green), discharged to $1.95 \mathrm{~V}$ (pink), charged to $4.00 \mathrm{~V}$ (cyan) and (b) $\mathrm{Li}_{0.97} \mathrm{~V}_{2} \mathrm{O}_{3}\left(\mathrm{SO}_{4}\right)_{2}$ (teal), $\mathrm{Li}_{1.64} \mathrm{~V}_{2} \mathrm{O}_{3}\left(\mathrm{SO}_{4}\right)_{2}$ (yellow), $\mathrm{Li}_{2.47} \mathrm{~V}_{2} \mathrm{O}_{3}\left(\mathrm{SO}_{4}\right)_{2}$ (maroon), $\mathrm{Li}_{3.97} \mathrm{~V}_{2} \mathrm{O}_{3}\left(\mathrm{SO}_{4}\right)_{2}$ (purple). the $\mathrm{V}=\mathrm{O}$ bond of the $[\mathrm{VO}]^{3+}$ unit should increase in length on insertion of $2.0 \mathrm{Li}^{+}$which would form two $[\mathrm{VO}]^{2+}$ species. On insertion of $4.0 \mathrm{Li}^{+}$, the $\mathrm{Li}_{3.97} \mathrm{~V}_{2} \mathrm{O}_{3}\left(\mathrm{SO}_{4}\right)_{2}$ phase should not contain any short $\mathrm{V}=\mathrm{O}$ bonds, as these are absent in $\mathrm{V}^{3+}$ phases. ${ }^{38}$ The absorption band $\left(993 \mathrm{~cm}^{-1}\right)$ corresponding to the short $\mathrm{V}=\mathrm{O}$ bond shifts with varying $\mathrm{Li}^{+}$content. ${ }^{23}$ Fig. 6(a) shows the $\mathrm{V}=\mathrm{O}$ absorption band of $\mathrm{V}_{2} \mathrm{O}_{3}\left(\mathrm{SO}_{4}\right)_{2}$ discharged to $3.50 \mathrm{~V}, 2.95 \mathrm{~V}, 2.40 \mathrm{~V}$ and $1.95 \mathrm{~V}$ shifts to lower frequencies of $983 \mathrm{~cm}^{-1}, 985 \mathrm{~cm}^{-1}, 975 \mathrm{~cm}^{-1}$ and $975 \mathrm{~cm}^{-1}$, respectively, relative to $\mathrm{V}_{2} \mathrm{O}_{3}\left(\mathrm{SO}_{4}\right)_{2}\left(993 \mathrm{~cm}^{-1}\right)$. While the $\mathrm{V}=\mathrm{O}$ absorption band of the $\mathrm{V}_{2} \mathrm{O}_{3}\left(\mathrm{SO}_{4}\right)_{2}$ electrode charged to $4.00 \mathrm{~V}$ shifted to a higher frequency $989 \mathrm{~cm}^{-1}$, relative to the electrode discharged to $1.95 \mathrm{~V}\left(975 \mathrm{~cm}^{-1}\right)$. This shift suggests the $\mathrm{V}=\mathrm{O}$ bond length increases with increasing $\mathrm{Li}^{+}$content and contracts on extraction of $\mathrm{Li}^{+}$which coincides with the XANES data.

Fig. 6(b) shows that $\mathrm{V}=\mathrm{O}$ absorption band also shifts to lower frequencies of $985 \mathrm{~cm}^{-1}, 984 \mathrm{~cm}^{-1}$ and $975 \mathrm{~cm}^{-1}$ for $\mathrm{Li}_{0.97} \mathrm{~V}_{2} \mathrm{O}_{3}\left(\mathrm{SO}_{4}\right)_{2}, \mathrm{Li}_{1.64} \mathrm{~V}_{2} \mathrm{O}_{3}\left(\mathrm{SO}_{4}\right)_{2}$ and $\mathrm{Li}_{2.47} \mathrm{~V}_{2} \mathrm{O}_{3}\left(\mathrm{SO}_{4}\right)_{2}$, respectively, demonstrating that the $\mathrm{V}=\mathrm{O}$ bond length increases. In the case of $\mathrm{Li}_{3.97} \mathrm{~V}_{2} \mathrm{O}_{3}\left(\mathrm{SO}_{4}\right)_{2}$, the intensity of the $\mathrm{V}=\mathrm{O}$ bond almost disappears, suggesting that $\mathrm{Li}_{3.97} \mathrm{~V}_{2} \mathrm{O}_{3}\left(\mathrm{SO}_{4}\right)_{2}$ does not contain the short vanadyl bond - consistent with a $\mathrm{V}^{3+}$ phase. ${ }^{14,38}$

Interestingly, the lithiated phases exhibit an additional absorption band at $880 \mathrm{~cm}^{-1}$, not observed for $\mathrm{V}_{2} \mathrm{O}_{3}\left(\mathrm{SO}_{4}\right)_{2}$. This band $\left(880 \mathrm{~cm}^{-1}\right)$ is consistent with a longer $\mathrm{V}-\mathrm{O}$ bond. ${ }^{23,39,40}$ Its frequency suggests that it is longer than the other $\mathrm{V}-\mathrm{O}$ bonds which exhibit absorption bands in the frequency range 934$960 \mathrm{~cm}^{-1}$. This implies a change in the local structure around vanadium which will be discussed further in the subsequent section.

\section{Structural evolution}

To reveal the structural changes with $\mathrm{Li}^{+}$content, EXAFS analysis and PXRD studies were performed. Information on the changes in the local structure of the vanadium atoms was obtained by fitting the EXAFS data. A model based on the structure of the pristine phase, $\mathrm{V}_{2} \mathrm{O}_{3}\left(\mathrm{SO}_{4}\right)_{2}$, was used to fit the EXAFS spectra. The local structure of vanadium in $\mathrm{V}_{2} \mathrm{O}_{3}\left(\mathrm{SO}_{4}\right)_{2}$ is complex and the local environment of the $\mathrm{V}(1)$ and $\mathrm{V}(2)$ atoms is shown in Fig. $7 .^{24}$ Each vanadium atom is coordinated via six 


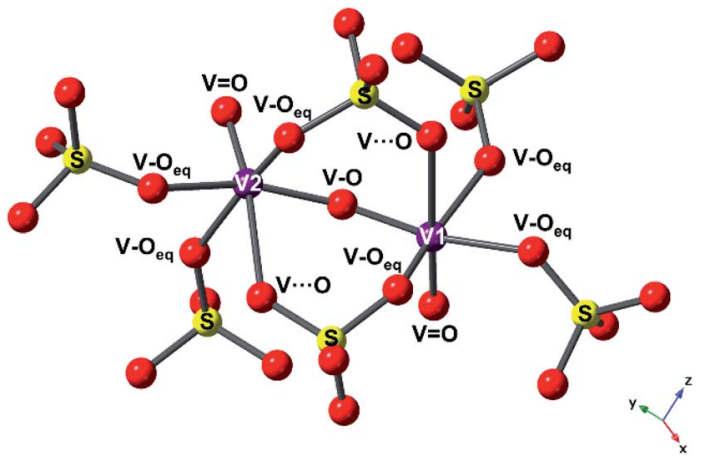

Fig. 7 Local environment of $\mathrm{V}(1)$ and $\mathrm{V}(2)$ atoms in $\mathrm{V}_{2} \mathrm{O}_{3}\left(\mathrm{SO}_{4}\right)_{2}$, showing the different paths used in the EXAFS fitting model $((\mathrm{V}=\mathrm{O})+$ $\left.(\mathrm{V}-\mathrm{O})+\left(\mathrm{V}-\mathrm{O}_{\mathrm{eq}}\right)+(\mathrm{V} \cdots \mathrm{O})+(\mathrm{V}-\mathrm{O}-\mathrm{S})\right)$, with the vanadium atoms shown as purple spheres, oxygen atoms as red spheres and sulfur atoms as yellow spheres.

$\mathrm{V}-\mathrm{O}$ bonds (Table $\mathrm{S} 2 \dagger$ ). The vanadium atoms are both coordinated to a short terminal oxygen atom, $\mathrm{V}(1)=\mathrm{O}(1)$ at $1.598(8) \AA$ and $\mathrm{V}(2)=\mathrm{O}(2)$ at $1.590(3) \AA$, and interconnected by a bridging oxygen atom, $\mathrm{O}(3)$, with $\mathrm{V}(1)=\mathrm{O}(3)$ at $1.686(7) \AA$ and $\mathrm{V}(2)-\mathrm{O}(3)$ at an intermediate length of 1.781(4) $\AA$, forming $\left[\mathrm{V}(1) \mathrm{O}_{2}\right]^{+}$and $[\mathrm{V}(2) \mathrm{O}]^{3+}$. Each vanadium atom also shows three intermediate bonds, $\mathrm{V}-\mathrm{O}_{\text {eq }}(\sim 1.95(5) \AA)$, and one long bond, $\mathrm{V} \cdots \mathrm{O}(\sim 2.32(2)$ $\AA)$. Since the environments of $\mathrm{V}(1)$ and $\mathrm{V}(2)$ are similar, this structure was simplified into a five-path model consisting of a path for the short vanadyl bond $(\mathrm{V}=\mathrm{O})$, one for the short intermediate bond $(\mathrm{V}-\mathrm{O})$, one for the three equatorial bonds $(\mathrm{V}-$ $\left.\mathrm{O}_{\mathrm{eq}}\right)$, one for the long bond $(\mathrm{V} \cdots \mathrm{O})$ and one for the $\mathrm{V}-\mathrm{O}-\mathrm{S}$ coordination, as illustrated in Fig. 7. During the fitting process, the atomic separations were refined, the coordination number $(N)$ was held constant and one photoelectron energy shift $\left(E_{\mathrm{o}}\right)$ was fitted for the five paths. An amplitude reduction factor $\left(S_{\mathrm{o}}{ }^{2}\right)$ of 1.0 was obtained by fitting the data from the pristine phase and used in the fitting of the data from lithiated materials. A different disorder factor $\left(\sigma^{2}\right)$ for each path was used and fitting ranges of $4.0<k<13.0 \AA^{-1}$ and $1.0<R<4.0 \AA$ were employed. The fit values for $E_{\mathrm{O}}$ remained within $\pm 10 \mathrm{eV}$. The experimental $k^{3}$-weighted EXAFS data fitted with the five-path model and the $k^{3}$-weighted Fourier Transform of the EXAFS for the electrochemically lithiated samples are shown in Fig. 8(a) and (b), respectively. The experimental $k^{3}$-weighted EXAFS data fitted with the five-path model and the $k^{3}$-weighted Fourier transform (a)

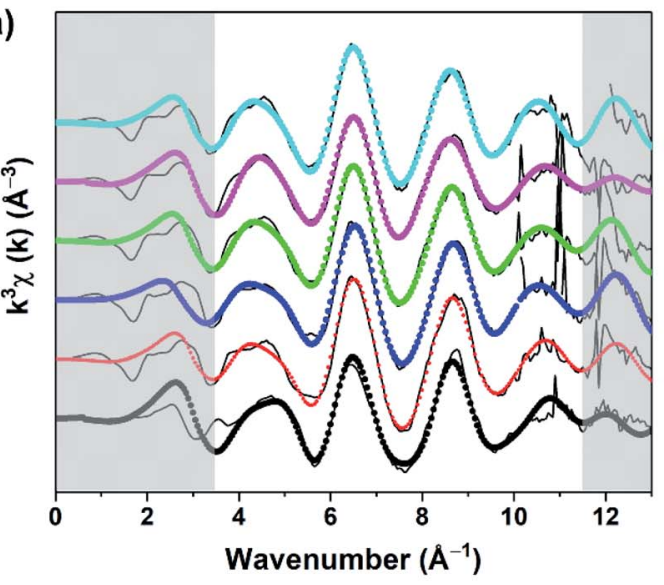

(c)

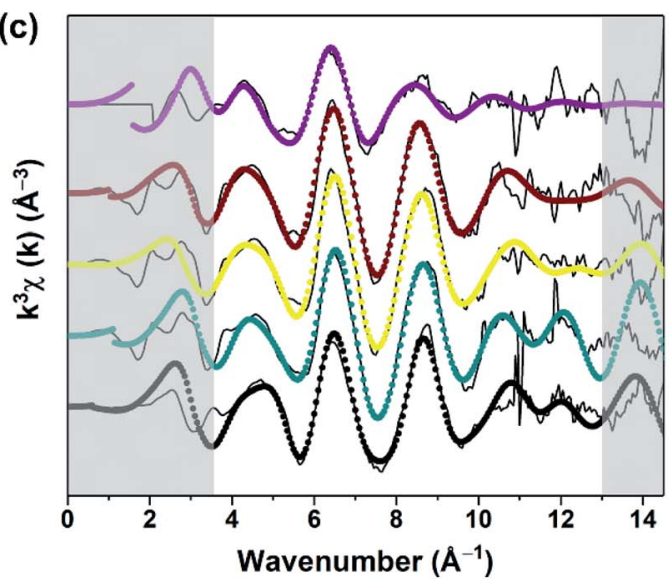

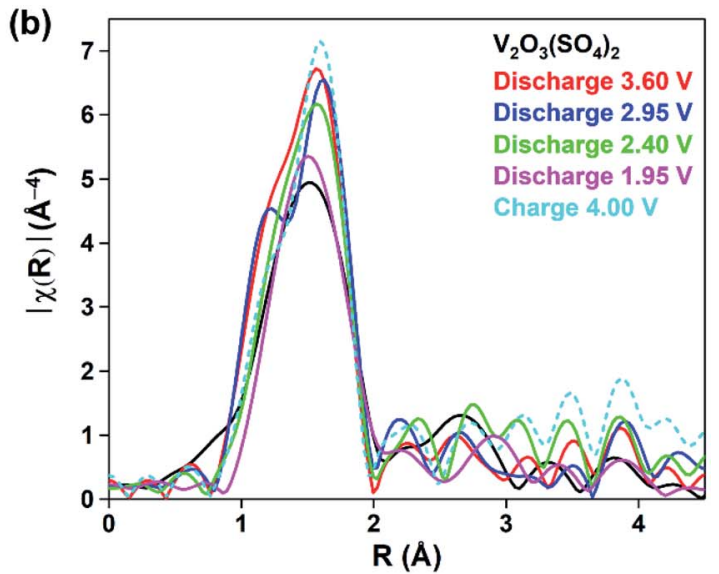

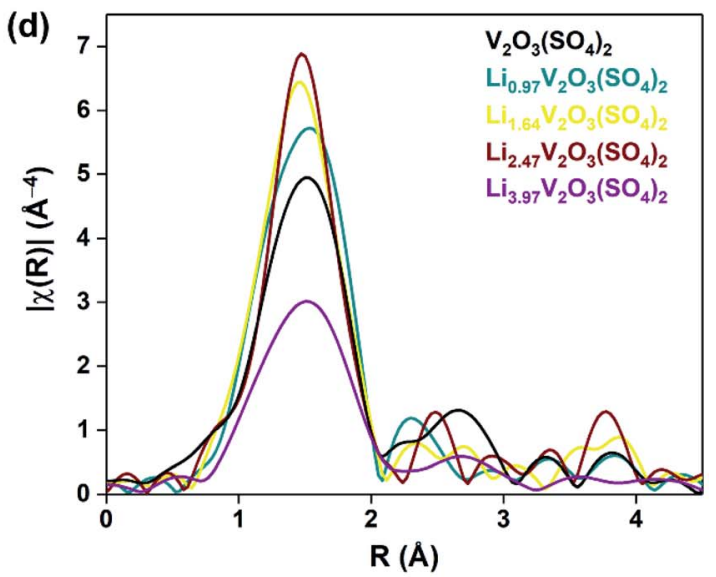

Fig. 8 (a) Experimental $k^{3}$-weighted EXAFS data (black lines) fitted with the five-path model (filled circles) and (b) their corresponding vanadium $\mathrm{K}$-edge EXAFS spectra Fourier Transform in the R-space for the $\mathrm{V}_{2} \mathrm{O}_{3}\left(\mathrm{SO}_{4}\right)_{2}$ electrode at various states of discharge and charge, (c) experimental $k^{3}$-weighted EXAFS data (black lines) fitted with the five-path model (filled circles) and (d) their corresponding vanadium $\mathrm{K}$-edge EXAFS spectra Fourier Transform in the $R$-space for the chemically lithiated phases. 
of the EXAFS for the chemically lithiated samples are shown in Fig. 8(c) and (d), respectively. Note that the peaks of the $k^{3}$ weighted Fourier Transform have not been phase-shift corrected and appear at shorter distances than the atomic separations they represent.

Fig. 8(b) and (d) each show one distinct peak positioned in the 1-2 A range, associated with the $\mathrm{V}-\mathrm{O}$ local environment of the first coordination sphere with the majority of this peak originating from the three $\mathrm{V}-\mathrm{O}_{\text {eq }}$ bonds. ${ }^{32,33}$ The following peaks extending to $3.5 \AA$ are dominated by contributions from the long $\mathrm{V} \cdots \mathrm{O}$ bond and the $\mathrm{V}-\mathrm{S}$ single scattering paths. They show variations in the amplitude of the $\mathrm{V}-\mathrm{O}$ contribution with $\mathrm{Li}^{+}$ content, suggesting changes in the local arrangement of the first coordination sphere surrounding the vanadium atoms. Fig. 8(b) shows that the amplitude of the first peak increased after discharging to $3.60 \mathrm{~V}$ due to $\mathrm{Li}^{+}$insertion. The amplitude of this peak decreases on insertion of more $\mathrm{Li}^{+}$and increases again after extraction of $\mathrm{Li}^{+}$.

The results from the fits of the EXAFS for the electrochemically lithiated samples are presented in Table S4. $\dagger$ The bond lengths for $\mathrm{V}_{2} \mathrm{O}_{3}\left(\mathrm{SO}_{4}\right)_{2}$ are comparable to the bond lengths obtained from PXRD analysis (Table S2 $\dagger$ ). On cycling $\mathrm{V}_{2} \mathrm{O}_{3}\left(\mathrm{SO}_{4}\right)_{2}$ vs. $\mathrm{Li}^{+} / \mathrm{Li}^{0}$, the $\mathrm{V}=\mathrm{O}$ bond length fluctuated but remained within the range of a vanadyl bond $(1.56(6)-1.60(4) \AA) .{ }^{38}$ This result was expected since the electrochemical data and XANES spectra both suggested that $\mathrm{V}^{5+}$ was reduced to $\mathrm{V}^{4+}$ which also contains a $\mathrm{V}=\mathrm{O}$ bond. ${ }^{38}$ The $\mathrm{V}-\mathrm{O}$ bond, which models the bridging oxygen atom between to the two vanadium atoms increased in length to $1.83(5) \AA$ after discharge to $1.95 \mathrm{~V}$. This is consistent with a transition from $\mathrm{V}^{5+}$ to $\mathrm{V}^{4+}$ (i.e., $\left[\mathrm{VO}_{2}\right]^{+}$to $[\mathrm{VO}]^{2+}$ ) on insertion of $2.0 \mathrm{Li}^{+}$per mol of $\mathrm{V}_{2} \mathrm{O}_{3}\left(\mathrm{SO}_{4}\right)_{2}$. On extraction of $\mathrm{Li}^{+}$, the $\mathrm{V}-\mathrm{O}$ bond contracted again to 1.78(1) $\AA$ consistent with $\mathrm{a}[\mathrm{VO}]^{2+}$ to $\left[\mathrm{VO}_{2}\right]^{+}$transition, in agreement with the XANES data. Fig. 8(d) shows an increase in the amplitude of the first peak with increasing $\mathrm{Li}^{+}$content which can be attributed to a higher degree of symmetry surrounding the vanadium atoms with increasing $\mathrm{Li}^{+}$content. ${ }^{32,33}$

However, in the case of the $\mathrm{Li}_{3.97} \mathrm{~V}_{2} \mathrm{O}_{3}\left(\mathrm{SO}_{4}\right)_{2}$ phase, the intensity of the $\mathrm{V}-\mathrm{O}$ contribution decreased significantly. Since the symmetry surrounding the vanadium atoms continued to increase with increasing $\mathrm{Li}^{+}$, this effect was probably outweighed by an increase in the disorder as the $\mathrm{V}-\mathrm{O}$ bonds became longer and weaker. Fig. 8(c) shows the spectrum of $\mathrm{Li}_{3.97} \mathrm{~V}_{2} \mathrm{O}_{3}\left(\mathrm{SO}_{4}\right)_{2}$ is noisy, with no signal beyond $11 \AA^{-1}$ so the $k$-range was restricted to $3.6<k<10.8 \AA^{-1}$ and $1.0<R<4.0 \AA$. However, with this range the five-shell model gave nonsensical parameters, including either negative or extremely large disorder factors and $E_{\mathrm{o}}$ values greater than $10 \mathrm{eV}$. Consequently, other models were tested. A satisfactory fit was obtained with a four-path model consisting of a path for the two short vanadyl bonds $(\mathrm{V}=\mathrm{O})$, one for the three equatorial bonds $\left(\mathrm{V}-\mathrm{O}_{\mathrm{eq}}\right)$, one for the long bond $(\mathrm{V} \cdots \mathrm{O})$ and one for the $\mathrm{V}-\mathrm{O}-\mathrm{S}$ coordination. The fitting parameters show an increase in the $\mathrm{V}-\mathrm{O}$ bond lengths compared to the other samples. The short $\mathrm{V}=\mathrm{O}$ bond distance (1.67(2) $\mathrm{A}$ ) increased in length by $0.07 \AA$ compared to the pristine phase and is midway between the $\mathrm{V}=\mathrm{O}$ and $\mathrm{V}-\mathrm{O}-\mathrm{V}$ bond.
The equatorial bonds $\left(\mathrm{V}-\mathrm{O}_{\mathrm{eq}}\right)$ also increased in length (2.04(4) $\mathrm{A}$ ) and are consistent with $\mathrm{V}^{3+}-\mathrm{O}$ bond lengths. ${ }^{41}$ These results are broadly consistent with the reduction of $\mathrm{V}^{5+}$ to $\mathrm{V}^{3+}$, since longer and weaker bonds were obtained from this analysis. Additionally, there is more disorder associated with the $\mathrm{V}-\mathrm{O}$ bonds of $\mathrm{Li}_{3.97} \mathrm{~V}_{2} \mathrm{O}_{3}\left(\mathrm{SO}_{4}\right)_{2}$ which is also consistent with $\mathrm{V}^{3+}-\mathrm{O}$ bonds. Moreover, there is a correlation between the intensity of the pre-edge peak of the XANES spectrum and the size of the $\mathrm{VO}_{x}$ coordination sphere. ${ }^{31}$ The reduced intensity of the pre-edge peak of $\mathrm{Li}_{3.97} \mathrm{~V}_{2} \mathrm{O}_{3}\left(\mathrm{SO}_{4}\right)_{2}$ relative to the other phases is consistent with the disappearance of the $\mathrm{V}=\mathrm{O}$ bond. This observation is consistent with the IR spectrum for this phase, suggesting $\mathrm{Li}_{3.97} \mathrm{~V}_{2} \mathrm{O}_{3}\left(\mathrm{SO}_{4}\right)_{2}$ consists of more regular $\mathrm{VO}_{6}$ octahedra compared to the distorted $\mathrm{VO}_{6}$ octahedra of $\mathrm{V}_{2} \mathrm{O}_{3}\left(\mathrm{SO}_{4}\right)_{2}$.

To follow the long-range structural changes, PXRD patterns of the lithiated phases were collected. Fig. 9(a) compares the PXRD patterns of the electrochemically lithiated samples and Fig. 9(b) compares the PXRD patterns of the chemically lithiated samples. The lithiated materials show no additional reflections compared to $\mathrm{V}_{2} \mathrm{O}_{3}\left(\mathrm{SO}_{4}\right)_{2}$, implying no secondary phases were formed on $\mathrm{Li}^{+}$insertion. Fig. 9 reveals a shift of the reflections for the lithiated samples relative to $\mathrm{V}_{2} \mathrm{O}_{3}\left(\mathrm{SO}_{4}\right)_{2}$, suggesting the unit cell volume changed on $\mathrm{Li}^{+}$insertion. It can be assumed that the lithiated materials retained the monoclinic symmetry of $\mathrm{V}_{2} \mathrm{O}_{3}\left(\mathrm{SO}_{4}\right)_{2}$ since the PXRD patterns of $\mathrm{V}_{2} \mathrm{O}_{3}\left(\mathrm{SO}_{4}\right)_{2}$ and the lithiated phases are similar.

To establish the changes in the unit cell parameters, a series of Rietveld refinements were performed using the structural model of $\mathrm{V}_{2} \mathrm{O}_{3}\left(\mathrm{SO}_{4}\right)_{2}$ as the starting model. ${ }^{24}$ The same general procedure was followed for each refinement, the backgrounds were fitted using a Chebyshev polynomial with 36 terms, the unit cell parameters, zero-error and profile parameters were all refined. Good fits were obtained and the fits between 9-12 $2 \theta$ are presented in Fig. $\mathrm{S} 3(\mathrm{a}-\mathrm{j}), \dagger$ highlighting the shifts of the reflections relative to the pristine phase. The corresponding changes in the unit cell parameters are given in Table S3. $\dagger$ The relationship between the $\mathrm{Li}$ content $\left(x \mathrm{Li}\right.$ in $\left.\mathrm{Li}_{x} \mathrm{~V}_{2} \mathrm{O}_{3}\left(\mathrm{SO}_{4}\right)_{2}\right)$ and the unit cell volume for the electrochemically lithiated samples is illustrated in Fig. 9(c). This shows there was an expansion of the unit cell volume of roughly $3.5 \%$ on insertion of $0.39 \mathrm{~mol} \mathrm{Li}^{+}$ after discharging to $3.60 \mathrm{~V}$. This can be explained by the sizeexpansion of the $\mathrm{VO}_{6}$ octahedra due to the partial reduction of $\mathrm{V}^{5+}$ to $\mathrm{V}^{4+}$ and the insertion of $\mathrm{Li}^{+} .^{42}$ Inserting more $\mathrm{Li}^{+}$caused the unit cell volume to contract. This can be rationalised by the increased electrostatic attraction with increasing $\mathrm{Li}^{+}$content which outweighed the size-expansion of the $\mathrm{VO}_{6}$ octahedra due to the reduction of $\mathrm{V}^{5+}$ to $\mathrm{V}^{4+}$. If $1.0 \mathrm{Li}^{+}$was inserted into $\mathrm{V}_{2} \mathrm{O}_{3}\left(\mathrm{SO}_{4}\right)_{2}$, according to the linear relationship shown in Fig. 9(c), $\mathrm{LiV}_{2} \mathrm{O}_{3}\left(\mathrm{SO}_{4}\right)_{2}$ would have a unit cell volume of $836(1)$ $\AA^{3}$. This corresponds to a 3.1(1)\% volume expansion relative to the pristine phase. This volume change is comparable with volume changes reported in the literature for other vanadiumbased polyanionic electrode materials. ${ }^{\mathbf{1 3 , 1 4 , 1 8}}$

The evolution of the unit cell volume after chemical lithiation is presented in Fig. 9(d). This shows the relationship between the $\mathrm{Li}^{+}$content $\left(x \mathrm{Li}\right.$ in $\left.\mathrm{Li}_{x} \mathrm{~V}_{2} \mathrm{O}_{3}\left(\mathrm{SO}_{4}\right)_{2}\right)$ obtained from ICP-OES analysis and the unit cell volume obtained from the 
(a)
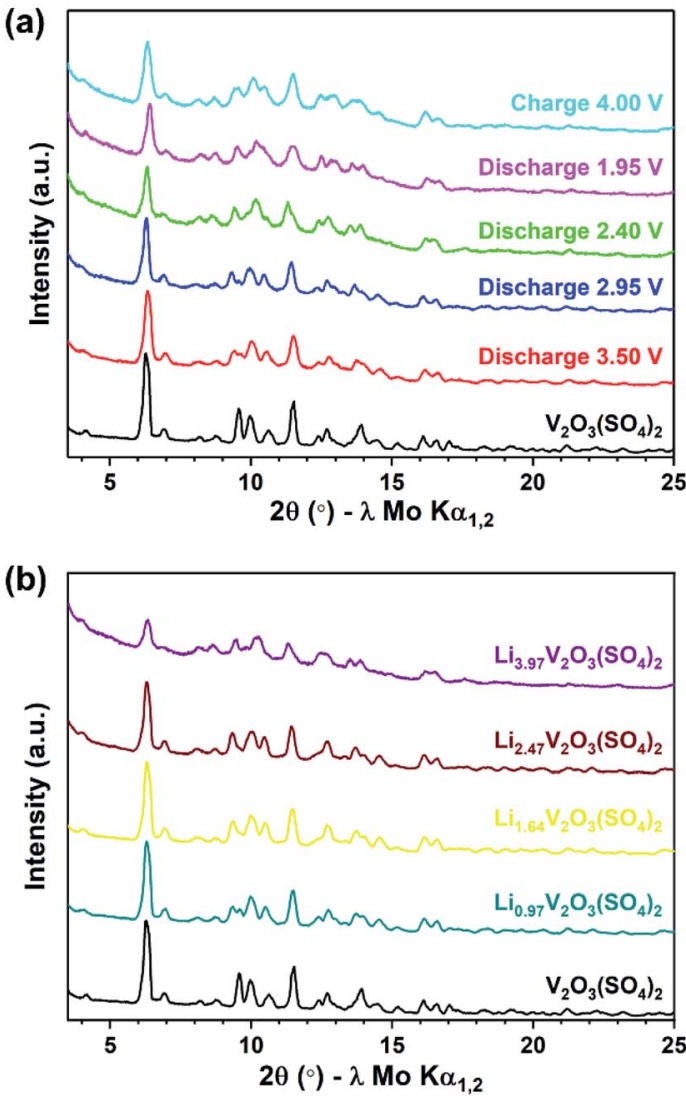

(c)
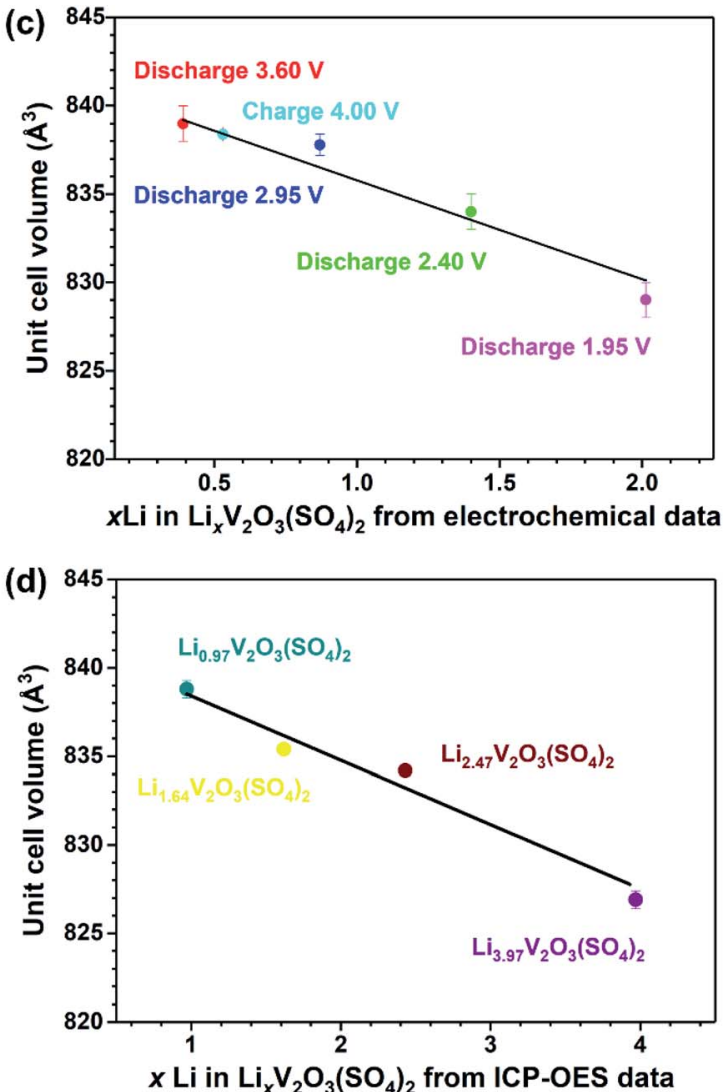

Fig. 9 (a) PXRD patterns of $\mathrm{V}_{2} \mathrm{O}_{3}\left(\mathrm{SO}_{4}\right)_{2}$ (black), $\mathrm{V}_{2} \mathrm{O}_{3}\left(\mathrm{SO}_{4}\right)_{2}$ electrode discharged to $3.50 \mathrm{~V}$ (red), discharged to $2.95 \mathrm{~V}$ (blue), discharged to $2.40 \mathrm{~V}$ (green), discharged to $1.95 \mathrm{~V}$ (pink), charged to $4.00 \mathrm{~V}$ (cyan), (b) PXRD patterns of the chemically lithiated phases, $\mathrm{Li}_{0.97} \mathrm{~V}_{2} \mathrm{O}_{3}\left(\mathrm{SO}_{4}\right)_{2}$ (teal), $\mathrm{Li}_{1.64} \mathrm{~V}_{2} \mathrm{O}_{3}\left(\mathrm{SO}_{4}\right)_{2}$ (yellow), $\mathrm{Li}_{2.47} \mathrm{~V}_{2} \mathrm{O}_{3}\left(\mathrm{SO}_{4}\right)_{2}$ (maroon) and $\mathrm{Li}_{3.97} \mathrm{~V}_{2} \mathrm{O}_{3}\left(\mathrm{SO}_{4}\right)_{2}$ (purple), (c) the effect of $x \mathrm{Li}$ in $\mathrm{Li}_{x} \mathrm{~V}_{2} \mathrm{O}_{3}\left(\mathrm{SO}_{4}\right)_{2}$ based on electrochemical data on the unit cell volume of electrochemically lithiated materials and (d) the effect of $x \mathrm{Li}_{\text {in }} \mathrm{Li}_{x} \mathrm{~V}_{2} \mathrm{O}_{3}\left(\mathrm{SO}_{4}\right)_{2}$ as determined from ICP-OES analysis on the unit cell volume of chemically lithiated materials.

Rietveld refinements. Fig. 9(d) shows the unit cell volume decreased linearly with increasing $\mathrm{Li}^{+}$content. This result coincides with the change in unit cell volume observed for the electrochemically lithiated materials, demonstrating that the structural changes during the electrochemical lithiation were replicated chemically.

\section{Conclusions}

This work has investigated for the first time the $\mathrm{Li}^{+}$insertion process into $\mathrm{V}_{2} \mathrm{O}_{3}\left(\mathrm{SO}_{4}\right)_{2}$ via electrochemical and chemical routes. $\mathrm{V}_{2} \mathrm{O}_{3}\left(\mathrm{SO}_{4}\right)_{2}$ delivers an initial discharge capacity of approximately $160 \mathrm{~mA} \mathrm{~h} \mathrm{~g}^{-1}$, corresponding to the insertion of approximately $2.0 \mathrm{Li}^{+}$per formula unit, associated with four redox processes at $4.09 \mathrm{~V}, 3.25 \mathrm{~V}, 2.83 \mathrm{~V}$ and $2.23 \mathrm{~V}$ attributed to the $\mathrm{V}^{4+} / \mathrm{V}^{5+}$ redox couple. XANES measurements of the electrochemically lithiated materials showed that $2.0 \mathrm{Li}^{+}$ions were incorporated to give $\mathrm{Li}_{2} \mathrm{~V}_{2} \mathrm{O}_{3}\left(\mathrm{SO}_{4}\right)_{2}$. As for the chemically lithiated materials, ICP-OES data and XANES measurements revealed that up to $4.0 \mathrm{Li}^{+}$ions can be inserted into $\mathrm{V}_{2} \mathrm{O}_{3}\left(\mathrm{SO}_{4}\right)_{2}$, reducing $\mathrm{V}^{5+}$ to $\mathrm{V}^{3+}$. Structural studies by PXRD revealed that the monoclinic symmetry of $\mathrm{V}_{2} \mathrm{O}_{3}\left(\mathrm{SO}_{4}\right)_{2}$ was retained with $\mathrm{Li}^{+}$insertion and was accompanied by changes in the unit cell volume. This analysis showed that the structural transformation which occurred during electrochemical lithiation was replicated chemically and that $4.0 \mathrm{Li}^{+}$ions can be inserted into $\mathrm{V}_{2} \mathrm{O}_{3}\left(\mathrm{SO}_{4}\right)_{2}$ while it maintained its framework structure.

This material exploits the property of vanadium to adopt numerous oxidation states and offers structural stability. This highlights the potential of vanadium sulfates and the opportunities to explore new vanadium-based polyanionic compounds.

\section{Conflicts of interest}

There are no conflicts to declare.

\section{Acknowledgements}

The authors thank M. Nowosielska for ICP-OES measurements. The authors are grateful for the provision of beam time and assistance from Dr Giannantonio Cibin on B18 at the Diamond Light Source (as part of the Energy Materials Block Allocation Group SP14239) and Dr Ron Smith on the GEM diffractometer at ISIS Neutron and Muon Source at the Rutherford Appleton 
Laboratory. The authors also thank EPSRC for funding of SFL's PhD thesis (EP/N509759/1).

\section{References}

1 M. S. Whittingham, Chem. Rev., 2004, 104, 4271-4301.

2 A. Manthiram and J. B. Goodenough, J. Power Sources, 1989, 26, 403-408.

3 C. Masquelier and L. Croguennec, Chem. Rev., 2013, 113, 6552-6591.

4 Y. Wang, Y. Wang, E. Hosono, K. Wang and H. Zhou, Angew. Chem., Int. Ed., 2008, 47, 7461-7465.

5 J. Wang and X. Sun, Energy Environ. Sci., 2012, 5, 5163-5185. 6 P. Barpanda, M. Ati, B. C. Melot, G. Rousse, J.-N. Chotard, M.-L. Doublet, M. T. Sougrati, S. A. Corr, J.-C. Jumas and J.-M. Tarascon, Nat. Mater., 2011, 10, 772-779.

7 M. Kim, Y. Jung and B. Kang, J. Mater. Chem. A, 2015, 3, 7583-7590.

8 R. K. B. Gover, P. Burns, A. Bryan, M. Y. Saidi, J. L. Swoyer and J. Barker, Solid State Ionics, 2006, 177, 2635-2638.

9 J. Barker, R. K. B. Gover, P. Burns, A. Bryan, M. Y. Saidi and J. L. Swoyer, J. Power Sources, 2005, 146, 516-520.

10 J. Barker, R. K. B. Gover, P. Burns, A. Bryan, M. Y. Saidi and J. L. Swoyer, J. Electrochem. Soc., 2005, 152, A1776-A1779.

11 J. Barker, R. K. B. Gover, P. Burns and A. Bryan, Electrochem. Solid-State Lett., 2005, 8, A285-A287.

12 J.-M. Ateba Mba, C. Masquelier, E. Suard and L. Croguennec, Chem. Mater., 2012, 24, 1223-1234.

13 M. Bianchini, J. M. Ateba-Mba, P. Dagault, E. Bogdan, D. Carlier, E. Suard, C. Masquelier and L. Croguennec, J. Mater. Chem. A, 2014, 2, 10182-10192.

14 K. L. Harrison, C. A. Bridges, C. U. Segre, C. D. V. Jr, D. Applestone, C. W. Bielawski, M. P. Paranthaman and A. Manthiram, Chem. Mater., 2014, 26, 3849-3861.

15 J. Barker, M. Y. Saidi and J. L. Swoyer, J. Electrochem. Soc., 2004, 151, A796-A800.

16 M. S. Kishore, V. Pralong, V. Caignaert, U. V. Varadaraju and B. Raveau, Electrochem. Commun., 2006, 8, 1558-1562.

17 M. Satya Kishore, V. Pralong, V. Caignaert, S. Malo, S. Hebert, U. V. Varadaraju and B. Raveau, J. Solid State Chem., 2008, 181, 976-982.

18 M. Sun, G. Rousse, M. Saubanère, M.-L. Doublet, D. Dalla Corte and J.-M. Tarascon, Chem. Mater., 2016, 28, 6637-6643.

19 J. Gaubicher, Y. Chabre, J. Angenault, A. Lautié and M. Quarton, J. Alloys Compd., 1997, 262-263, 34-38.

20 K. S. Nanjundaswamya, H. Araib, J. Yamakib, S. Okadab and H. Ohtsukab, Solid State Ionics, 1996, 92, 1-10.
21 J. Gaubicher, J. Angenaut, Y. Chabre, T. Le Mercier and M. Quarton, Mol. Cryst. Liq. Cryst., 1998, 311, 45-50.

22 L. Lander, J.-M. Tarascon and A. Yamada, Chem. Rec., 2018, 18, 1394-1408.

23 K.-L. Richter and R. Mattes, Z. Anorg. Allg. Chem., 1992, 611, 158-164.

24 B. H. Toby, J. Appl. Crystallogr., 2001, 34, 210-213.

25 A. C. Larson and R. B. Von Dreele, GSAS - General Structure Analysis System, LANL Report, Los Alamos National Laboratory, LAUR, Los Alamos, USA, 2001, pp. 86-748.

26 B. Ravel and M. Newville, Phys. Scr., 2005, 115, 1007-1010.

27 B. Ravel and M. Newville, J. Synchrotron Radiat., 2005, 12, 537-541.

28 T. Ohzuku, J. Kato, K. Sawai and T. Hirai, J. Electrochem. Soc., 1991, 138, 2556-2560.

29 H. Björk, T. Gustafsson, J. O. Thomas, S. Lidin and V. Petř́iček, J. Mater. Chem., 2003, 13, 585-589.

30 Y. J. Lee, F. Wang, S. Mukerjee, J. McBreen and C. P. Grey, J. Electrochem. Soc., 2000, 147, 803-812.

31 J. Wong, F. W. Lytle, R. P. Messmer and D. H. Maylotte, Phys. Rev. B: Condens. Matter Mater. Phys., 1984, 30, 5596-5610.

32 C. J. Allen, Q. Jia, C. N. Chinnasamy, S. Mukerjee and K. M. Abraham, J. Electrochem. Soc., 2011, 158, 1250-1259.

33 A. N. Mansour, P. H. Smith, W. M. Baker, M. Balasubramanian and J. McBreen, Electrochim. Acta, 2002, 47, 3151-3161.

34 T. Tsunehiro, Y. Hiromi, T. Risa, F. Takuzo and Y. Satohiro, J. Chem. Soc., 1988, 84, 2987-2999.

35 G. A. Horrocks, E. J. Braham, Y. Liang, L. R. De Jesus, J. Jude, J. M. Velázquez, D. Prendergast and S. Banerjee, J. Phys. Chem. C, 2016, 120, 23922-23932.

36 Y. U. Park, D. H. Seo, H. S. Kwon, B. Kim, J. Kim, H. Kim, I. Kim, H. I. Yoo and K. Kang, J. Am. Chem. Soc., 2013, 135, 13870-13878.

37 A. P. Tyutyunnik, V. N. Krasil, V. G. Zubkov, L. A. Perelyaeva and I. V Baklanova, Russ. J. Inorg. Chem., 2010, 55, 554-560.

38 M. Schindler, F. C. Hawthorne and W. H. Baur, Chem. Mater., 2000, 12, 1248-1259.

39 A. P. Tyutyunnik, V. G. Zubkov, I. F. Berger, V. N. Krasil, L. A. Perelyaeva and I. V Baklanova, Russ. J. Inorg. Chem., 2007, 52, 1521-1526.

40 V. N. Krasil'nikov, A. P. Tyutyunnik, L. A. Perelyaeva and I. V Baklanova, Russ. J. Inorg. Chem., 2013, 58, 161-167.

41 J. Krakowiak, D. Lundberg and I. Persson, J. Inorg. Chem., 2012, 51, 9598-9609.

42 R. D. Shannon, Acta Crystallogr., Sect. A: Cryst. Phys., Diffr., Theor. Gen. Crystallogr., 1976, 32, 751-767. 